\title{
MULTICULTURALISMO E TRABALHO: A PROTEÇÃO DO DIREITO DE LIBERDADE RELIGIOSA DE GRUPOS MINORITÁRIOS NO BRASIL
}

\author{
MULTICULTURALISM AND WORK: THE PROTECTION OF THE \\ RIGHT OF RELIGIOUS LIBERTY OF MINORITY GROUPS IN BRAZIL
}

\section{MULTICULTURALISMO Y TRABAJO: LA PROTECCIÓN DEL DERECHO DE LIBERTAD RELIGIOSA DE GRUPOS MINORITARIOS EN BRASIL}

\author{
ANA VIRGINIA MOREIRA GOMES* \\ Universidade de Fortaleza (UNIFOR), Fortaleza, Ceará, Brasil \\ ANDRÉ LUIZ SIENKIEVICZ MACHADO** \\ Universidade de Fortaleza (UNIFOR), Fortaleza, Ceará, Brasil
}

\begin{abstract}
Resumo: Desenvolvida pelo método de descrição crítico-explicativa próprio da Ciência do Direito, a pesquisa decorre da identificação da necessidade de ordenação sistemática de critérios jurídicos para a solução de conflitos decorrentes do encontro de elementos de diversidade religiosa no ambiente de trabalho, assumindo como hipótese a existência de sistema normativo de proteção dos grupos religiosos minoritários. Para a solução do problema, o propósito geral da investigação consiste em analisar, em uma sociedade multicultural como a brasileira, o âmbito de proteção do
\end{abstract}

\footnotetext{
* Pós-Doutorado na School of Industrial and Labor Relations da Cornell University (2007). Doutorado em Direito pela Universidade de São Paulo (2000). LL.M na Faculdade de Direito da University of Toronto (2009). Graduação em Direito pela Universidade Federal do Ceará (1994). Professora dos Cursos de Mestrado e Doutorado no Programa de Pós-Graduação em Direito Constitucional e do Curso de Graduação em Direito da Universidade de Fortaleza. Coordena o Núcleo de Estudos em Direito do Trabalho e Seguridade Social na Universidade de Fortaleza. Correio eletrônico: «avmgomes@gmail.com».

${ }^{* *}$ Mestrando no Programa de Pós-Graduação em Direito Constitucional da Universidade de Fortaleza. Especialista em Direito do Trabalho e Direito Processual do Trabalho pelo Centro Universitário Christus (2017). Graduado em Direito pela Universidade Federal do Paraná (2006). Exerce o cargo de Procurador do Estado do Ceará (2008-). Membro do Núcleo de Estudos sobre Direito do Trabalho e da Seguridade Social da Universidade de Fortaleza. Correio eletrônico: «andreluizufpr@hotmail.com».

Este trabajo fue recibido el 12 de octubre de 2018 y aprobado el 26 de diciembre de 2018.
} 
direito fundamental de liberdade de religião dos grupos minoritários no campo das relações de trabalho. De modo mais específico, examinam-se os elementos relacionados ao exercício desse direito fundamental na ambiência do trabalho, sobretudo diante de situações de tensão. Para isso, o artigo discute o alcance da proteção do direito fundamental de liberdade religiosa dos grupos minoritários no âmbito das relações contratuais de trabalho, utilizando como paradigma teórico o círculo de interação dialógica e reflexiva entre democracia, multiculturalismo e trabalho no contexto do Estado Democrático de Direito brasileiro. O estudo se inicia ao traçar o panorama da expansão dos grupos religiosos minoritários no Brasil. A análise parte para examinar criticamente o marco de regulação da proteção do direito de liberdade religiosa dos grupos minoritários e do combate a práticas de discriminação relacionadas ao trabalho. Por fim, o estudo descreve os conflitos mais comuns no processo dinâmico de interseção entre religião e trabalho, desenvolvendo critérios jurídicos para a solução desses conflitos.

Palavras-chave: Multiculturalismo; democracia; trabalho; liberdade religiosa; grupos minoritários.

\begin{abstract}
Developed by the critical-explanatory description method proper of Jurisprudence, the research results from the identification of the need for systematic ordering of legal criteria for the solution of conflicts arising from the confluence of religious diversity elements in the workplace, assuming as hypothesis the existence of a normative protection system of minority religious groups. In order to solve the problem, the general purpose of the research is to analyze, in a multicultural society such as the Brazilian one, the protection scope of the fundamental right to religious freedom of minority groups in the labor relations field. More specifically, it examines the elements related to the exercise of this fundamental right in the workplace, especially in situations of tension. For this, the paper discusses the scope of protection of the fundamental right of religious freedom of minority groups in contractual relations of work, using as theoretical paradigm the circle of dialogic and reflexive interaction between democracy, multiculturalism and work in the context of the Brazilian Democratic State of Law. The study begins with the outline of the expansion of minority religious groups in Brazil. The analysis sets out to critically examine the regulatory framework for the protection of minority groups' right to religious freedom and to fight discrimination related to work. Finally, the study describes the most common conflicts in the dynamic process of intersection between religion and work, developing legal criteria for the solution of these conflicts.
\end{abstract}

Keywords: Multiculturalism; democracy; labor; religious freedom; minority groups.

Resumen: Desarrollada por el método de descripción crítico-explicativa propio de la Ciencia del Derecho, la investigación se deriva de la identificación de la necesidad de ordenación sistemática de criterios jurídicos para la solución de conflictos resultantes del encuentro de elementos de diversidad religiosa en el ambiente de trabajo, asumiendo como hipótesis la existencia de un sistema normativo de protección de los grupos religiosos minoritarios. Para la solución del problema, el propósito general de la investigación consiste en analizar, en una sociedad multicultural como la brasileña, el ámbito de protección del derecho fundamental de libertad de religión de los grupos minoritarios en el campo de las relaciones de trabajo. De modo más específico, se examinan los elementos relacionados al ejercicio de ese derecho fundamental en el ambiente del trabajo, especialmente en situaciones de tensión. Para ello, el artículo discute el alcance de la protección del derecho fundamental de libertad religiosa de los grupos minoritarios en las relaciones contractuales de trabajo, utilizando como paradigma teórico el círculo de interacción dialógica y reflexiva entre democracia, multiculturalismo y trabajo en el Estado 
Democrático de Derecho brasileño. El estudio se inicia al trazar el panorama de la expansión de los grupos religiosos minoritarios en Brasil. El análisis sigue para examinar críticamente el marco de regulación de la protección del derecho de libertad religiosa de los grupos minoritarios y del combate a prácticas de discriminación en el trabajo. Por último, el estudio describe los conflictos más comunes en la intersección entre religión y trabajo, desarrollando criterios jurídicos para la solución de esos conflictos.

Palabras clave: Multiculturalismo; democracia; trabajo; libertad religiosa; grupos minoritarios.

\section{A Introdução}

A microfísica das relações de trabalho, em significativa medida, continua a operar em bases pouco democráticas e acentuadamente verticalizadas, em processos de dominação. Nelas, ainda há pouco espaço para o desenvolvimento de aspectos estranhos ao conteúdo propriamente econômico, que costuma alçar-se à condição de fim em si mesmo, tudo em nome da eficiência aferida em números, cifras e metas. Não se põe em questão a importância da dimensão econômica das relações de trabalho para a vida em sociedade, elemento essencial para o desenvolvimento. $\mathrm{O}$ econômico, nesse campo, comparece como parte da solução dos problemas da sociedade. Note-se bem: apenas como parte, e não como todo. Além disso, de forma ambivalente, também costuma atuar como fonte de criação e recrudescimento de problemas, precisamente em razão do elevado grau de hermetismo em relação a elementos de governança cidadã e democrática.

No ambiente democrático, porém, exige-se mais: o universo das relações de trabalho não se contém no campo econômico e nele não pode fechar-se. Estrutural e funcionalmente, a operação contratual de trabalho atua no campo existencial, como base necessária para a promoção do desenvolvimento sustentável em sentido mais amplo, inclusivo e humano. Por conseguinte, o econômico não pode subordinar nem anular o existencial.

O programa constitucional de abertura democrática do campo das relações sociais percorre áreas diversificadas e impõe desafios profundos e crescentemente complexos. No presente empreendimento de pesquisa, recorta-se pequeno - porém socialmente relevante - ponto desse amplo projeto: investigam-se elementos relacionados ao processo dinâmico de exercício do direito fundamental de liberdade religiosa dos grupos minoritários na ambiência do trabalho, no particular contexto do denominado multiculturalismo, fenômeno compreendido como a coexistência - e, mais do que isso, a convivência - de segmentos socioculturais marcados pela diversidade de expressões em determinado espaço político-geográfico.

O propósito geral da investigação consiste em analisar, em uma sociedade multicultural, como a brasileira, o âmbito de proteção do direito fundamental de liberdade de religião dos grupos minoritários no campo das relações de trabalho. De modo mais específico, examinam-se, com ênfase, os elementos relacionados ao exercício desse direito fundamental na ambiência do trabalho, sobretudo diante de situações de tensão.

Para isso, de início, nos três primeiros capítulos, destinados à fixação da matriz teórica e metodológica da investigação científica, identificam-se, no contexto do processo histórico de formação da sociedade brasileira, os movimentos de ininterrupta interação dialógica e circular de três campos: democracia, multiculturalismo e trabalho. No capítulo inaugural, examina-se a dinâmica da correlação entre trabalho e democracia, com destaque para a descrição dos efeitos 
reflexivos resultantes dessa interação. No segmento seguinte, estuda-se a interface entre democracia e multiculturalismo em recorte temporal mais amplo, com abrangência descritiva prognóstica relacionada aos processos emancipatórios dos grupos minoritários no ambiente social e político da globalização. Para arrematar a etapa de abertura metodológica da pesquisa, no capítulo quatro, cuida-se de traçar o panorama do multiculturalismo na ambiência de trabalho, com realce sobre os desafios provenientes desse encontro cada vez mais amplo e intenso.

Na sequência, no quinto capítulo, de forma breve, relata-se a inserção dos grupos religiosos minoritários na sociedade brasileira, com o exame de fatores que indicam a tendência de aumento dessa participação e os conflitos derivados de sua expansão. Logo adiante, no sexto capítulo, relaciona-se o direito fundamental de liberdade religiosa com a arquitetura jurídica estrutural da relação contratual de trabalho, para encartá-lo no campo mais amplo da autonomia privada existencial da pessoa do trabalhador. No passo seguinte, no capítulo sete, examinam-se os elementos integrantes da matriz constitucional das normas definidoras do direito fundamental de liberdade religiosa, com a descrição do âmbito de proteção desse direito.

Em seguida, no capítulo oito, incursiona-se verticalmente na análise da interação fisiológica do exercício do direito fundamental de liberdade religiosa com a execução da relação contratual de trabalho. De saída, nesse ponto, descreve-se, criticamente, o marco jurídico de regulação aplicável na regência da relação dinâmica entre o exercício do direito fundamental de liberdade religiosa dos grupos minoritários e a execução da relação contratual de trabalho, a começar pelos atos normativos de matriz internacional. Em seguida, no âmbito da ordem jurídica interna, com início na Constituição Federal, descreve-se o conjunto de direito positivo destinado a proteger os direitos dos grupos religiosos minoritários no campo das relações de trabalho e a solucionar as controvérsias derivadas dessa interação, com abrangência sobre os atos normativos de caráter mais geral e também sobre os estatutos específicos para proteção de determinados segmentos da classe trabalhadora. Nesse segmento, investiga-se, ainda, a adequação e suficiência desse acervo normativo para a tutela dos direitos da classe trabalhadora. Na sequência, para encerrar o capítulo oitavo, reportam-se as mais frequentemente encontradas tensões entre religião e trabalho, no contexto específico dos grupos minoritários. Relatam-se as práticas discriminatórias relacionadas à interseção desses dois campos em todas as etapas de desenvolvimento do ciclo contratual, isoladamente ou em associação com outros fatores geradores de preconceito. Nesse mesmo capítulo, discutem-se as possibilidades e os limites do exercício do direito de liberdade religiosa dos segmentos minoritários na ambiência do trabalho, com a assinalação dos conflitos mais recorrentes no eixo de espaço-tempo da execução do contrato e a indicação de critérios jurídicos para distensioná-los de forma adequada e eficiente.

\section{O trabalho e a democracia: um diálogo permanente (para o «bem»e para o «mal»)}

O trabalho ocupa papel central na estruturação do Estado Democrático de Direito inaugurado pela Constituição Federal de 1988 e na própria conformação da sociedade brasileira. O desenvolvimento econômico e humano opera-se, sobremaneira, a partir do trabalho e nele se realiza. Contudo, de um modo um tanto paradoxal, o progressivo processo de democratização do Estado e da sociedade, ainda carente de muitos aprimoramentos e avanços, percorre passos ainda mais vagarosos no campo das relações de trabalho. Precisamente, o paradoxo consiste no seguinte: o trabalho consubstancia-se em condição necessária para o desenvolvimento e para a democracia de modelo poliárquico (Dahl, 2006: 84), mas ele, em si, na sua microfísica e nos seus 
espaços, continua a ser, em enorme medida, o local do exercício autoritário de poder e o campo fértil para discriminação.

$\mathrm{Na}$ sua dimensão exógena ou centrífuga (de dentro para fora; do processo produtivo para a sociedade), o trabalho, com sensível protagonismo, apesar de numerosas falhas e percalços, desempenha a função de promover o desenvolvimento em bases democráticas. Na sua dimensão endógena ou centrípeta (microfísica do processo produtivo, dentro da empresa), o trabalho ou, mais especificamente, as relações de trabalho, não tanto em sua estrutura normativa, mas, sobretudo, na sua dinâmica, apresentam défice democrático ainda mais acentuado, a despeito da existência de todo um aparato regulatório e orgânico de proteção específica desse espaço relacional.

É dizer: o campo das relações de trabalho ainda precisa passar por ampla humanização levada a efeito por meio da «desreificação» mais abrangente e efetiva, para permitir que a pessoa abandone a condição de trabalhador-coisa (mero fator do processo produtivo) e passe ao estado de trabalhador-cidadão, com ampla possibilidade de desenvolvimento de sua personalidade conforme o seu projeto de vida. Evidentemente, a progressiva emancipação interna do trabalhador (tonar-se cidadão na empresa e no processo produtivo) produz consequências que exorbitam do círculo meramente produtivo e econômico para espraiar-se para os domínios mais amplos da vida em sociedade, em processo que, posto em marcha, apresenta a tendência de gerar um círculo virtuoso de democratização (Kolben, 2016: 75-76). É papel do Direito do Trabalho, por meio de regulação, fiscalização e fomento, estabelecer condições propícias para que esse tipo de dinâmica virtuosa se desenvolva (Deakin, 2016: 43). O círculo, porém, pode operar em sentido contrário e tornar-se vicioso: o défice democrático da sociedade exerce negativa interferência no campo da democracia interna das relações de trabalho e vice-versa.

\section{A democracia e o multiculturalismo: uma interação necessária (e cada vez mais intensa)}

No capítulo pregresso, cuidou-se da relação de imbricação entre trabalho e democracia e do processo dinâmico de interferência recíproca. Esses dois campos de interação são crescente e dialeticamente atravessados por fenômeno relativamente recente na experiência histórica mundial e, mais ainda, brasileira: o multiculturalismo (Bavaresco e Tacca, 2016: 62-64). A formação da sociedade brasileira resulta do processo de combinação de elementos étnicos, religiosos e linguísticos de origem diversificada. Ou seja, desde a origem, a sociedade brasileira assinala-se pela multiculturalidade.

Contudo, durante séculos, boa parte dos segmentos da sociedade representativos desses elementos de formação permaneceu em condição de ostracismo, relegada, por assim dizer, a guetos e, não raro, submetida a processos institucionalizados de preconceito, discriminação e perseguição. Parte desse quadro de invisibilidade social subsiste. $\mathrm{O}$ que, porém, existe de novo, diante do encontro aparentemente contraditório e excludente das afirmações postas no início da presente seção?

Sim, a sociedade brasileira, desde o princípio, apresenta a multiculturalidade como traço essencial do seu processo formativo, com a reunião contributiva e interativa de diversos elementos que lhe conferem identidade, da comida à música, das manifestações religiosas ao intercâmbio linguístico, e assim por diante (DaMatta, 1986: 10-11). Sim, também corresponde à verdade o fato de que, para o direito posto e para as instituições hegemônicas, essa diversidade 
formativa permaneceu invisibilizada diante da igualdade formalmente declarada ao longo de toda a experiência constitucional brasileira, desde 1824, mas com alcance muito reduzido e inefetivo diante do quadro mais amplo da diversidade constitutiva da sociedade nacional.

Em 1988, porém, com a inauguração do Estado do Democrático de Direito, a Constituição Federal criou condições para o reconhecimento da multiculturalidade inerente à formação da sociedade brasileira, a começar, no plano mais geral, pelo estabelecimento de amplo catálogo de direitos fundamentais que, ao contrário dos regimes anteriores, passaram a contar com eficácia imediata, sem a necessidade de intermediação legislativa ordinária, na maioria dos casos.

Além disso, o documento passou a prever, pela primeira vez ao longo da experiência histórica brasileira, proteção sistemática específica para grupos minoritários e para conjuntos de pessoas em situação de vulnerabilidade, como, por exemplo, a) as comunidades formadas por remanescentes dos quilombos (artigo 68 do Ato das Disposições Constitucionais Transitórias) e b) as pessoas com deficiência (artigos $7^{\circ}$, XXXI, 23, II, 24, XIV, 37, VIII, 203, IV e V, 208, III, $227, \S 1^{\circ}$, II, e $\S 2^{\circ}$, e 244 ), inclusive com o mandamento para a formação e desenvolvimento de políticas públicas especificamente voltadas a esse segmento da população.

A Constituição Federal de 1988 também tratou de ampliar e redesenhar o sistema de proteção de outros grupos minoritários e conjuntos de pessoas em situação de vulnerabilidade, como se deu, por exemplo, quanto aos povos indígenas ${ }^{1}$ e às mulheres. Em relação a elas, apenas para ilustrar exemplificativamente, assegurou-se igualdade plena de direitos e de deveres (artigo $5^{\circ}$, I), sem o prejuízo do reconhecimento da necessidade da adoção de políticas públicas específicas para a promoção da igualdade material, inclusive no mercado de trabalho (artigo $7^{\circ}$, $\mathrm{XX})$.

De modo mais amplo, reconhecer e assegurar a diferença para promover a igualdade material consiste na tônica que assinala o giro de multiculturalismo impulsionado pelo Estado Democrático de Direito em relação à emancipação e ao empoderamento de todos os segmentos minoritários e grupos de pessoas em situação de vulnerabilidade.

Mais do que tudo isso: a criação do ambiente democrático passou a permitir que todos esses grupos abandonassem o histórico papel de coadjuvação social para, paulatinamente, ganhar voz e vez e alcançar a condição de sujeitos-de-si, como protagonistas do próprio desenvolvimento, em um quadro crescente de afirmação, participação, reivindicação e conquista de direitos, como manifestação concreta da construção de uma «sociedade fraterna, pluralista e sem preconceitos», na forma preambularmente exortada pela Constituição Federal de 1988 (Martins e Mituzani, 2011: 349-350).

Evidentemente, o processo histórico, por intrínseca definição, constrói-se dinâmica e dialeticamente e, muitas vezes, de forma errática e até mesmo claudicante, e não de maneira linear, como se estivesse a percorrer uma estrada de ferro (Jouvenel, 1964: 87-88). De semelhante maneira, a ordem jurídica vai-se-construindo diante da evolução da experiência histórica:

\footnotetext{
1 Denominados, outrora, de silvícolas (habitantes das selvas, na literalidade do vocábulo), os regimes anteriores adotavam, explicitamente, a política voltada para a assimilação e o aculturamento, o que se pode comprovar com competência atribuída à União para cuidar da «incorporação dos silvícolas à comunhão nacional», presente nas Constituições de 1934 (artigo 5०, XIX, «m»), 1946 (artigo 5º XV, «r») e 1967 (artigo 8, XVII, «0») e na Emenda Constitucional $\mathrm{n}^{\circ}$ 1, de 1969 (artigo 8º XVII, «O»). Com a inauguração do Estado do Democrático de Direito, a política relativa aos povos indígenas passa por significativa reconstrução, com a afirmação da diferença como ferramenta para assegurar a igualdade: assim, passa-se a assegurar a essas populações os direitos relativos à «organização social, costumes, línguas, crenças e tradições» (artigo 231 da Constituição Federal).
} 
acompanha-a e dela faz parte e, portanto, também se sujeita a vicissitudes, inclusive retrocessos. Nesse sentido, a Constituição Federal de 1988, como marco de criação desse novo modelo de Estado e de sociedade, não atua como ponto de chegada, mas como ponto de partida e, nessa condição, deve reunir a capacidade de resiliência normativa para dar respostas adequadas aos novos desafios decorrentes desse processo evolutivo.

No particular contexto da presente pesquisa, a par da correlação dos diversificados elementos formativos que vieram a desembocar na construção do Estado Democrático de Direito, a recente experiência brasileira indica a contínua abertura para o acolhimento de novos aportes que intensificam esses traços de multiculturalidade. Por inevitável consequência, o ingresso dessas contribuiçõos resulta em possíveis (e não necessárias) tensões decorrentes da interação dialética dos novos elementos externos (elementos internalizados): a) com os elementos internos originários (formativos) e adventícios (anteriormente internalizados), e b) entre si.

O fluxo mais ou menos contínuo de ingresso de novos elementos de multiculturalidade na sociedade brasileira decorre, sobretudo, do avanço do processo de globalização, mas nele não se contém integralmente. Em grande medida, esse processo de esmaecimento de fronteiras reais e simbólicas se desenvolveu - e continua a desenvolver-se - no campo do comércio internacional, com o tráfego cada vez mais ampliado de mercadorias, serviços e investimentos. A centralidade do comércio no cenário de globalização não impede - ao contrário: produz como consequência o aumento de trocas internacionais em um sentido muito mais amplo, com alcance sobre informações, culturas, experiências e pessoas (Haas, 2011: 3).

O processo de globalização, com a abertura e a expansão de mercados, opera, em regra, como elemento de facilitação do deslocamento de pessoas entre fronteiras, e não, propriamente, como a causa exclusiva desses movimentos. Os deslocamentos duradouros de contingentes humanos formam-se, na origem, basicamente, por emigrantes, refugiados e exilados, que, no Brasil, regulam-se pela Lei $\mathrm{n}^{\mathbf{0}} 13.445$, de 2017, além, logicamente, de atos internacionais e da Constituição Federal.

Como tradição, o Brasil recebe aqueles que procuram o país para reconstruir a vida. Cuidase de característica formativa da própria sociedade brasileira, integrada, em parte, pelas correntes de emigração de pessoas vindas principalmente da Europa, sobretudo a partir de meados do Século XIX e da primeira metade do Século XX. O próprio processo de formação embrionária da ordem jurídica trabalhista brasileira contou com a participação decisiva desse contingente de trabalhadores imigrantes, com a deflagração de greves - com particular destaque à greve geral anarquista de 1917 - que, ao longo do tempo, redundaram na progressiva conquista de direitos para a classe trabalhadora, em lutas que, mais tarde, passariam a integrar, em definitivo, a própria identidade genética daquela ordem (Toledo, 2017: 501).

Agora, no Século XXI, o Brasil continua a receber novas levas de pessoas que deixam o país de origem em razão de episódios de guerra (Síria, por exemplo), catástrofes climáticas (Haiti, após o terremoto de 12.1.2010, por exemplo) e crises econômicas severas, como, para exemplificar, de forma mais recente, a Venezuela. Além disso, no fluxo do processo de globalização, com o estreitamento simbólico de distâncias e desadensamento de fronteiras, pessoas de todo o mundo procuram o país em busca de novas e melhores oportunidades, com origem em países em desenvolvimento, principalmente, mas também de países desenvolvidos, na esteira, por exemplo, da crise econômica sistêmica de 2007-2008.

Evidentemente, a despeito dessa tradição receptiva, nem tudo são flores para o estrangeiro. Além dos percalços inerentes ao processo emigratório, o estrangeiro pode deparar-se com atos de 
preconceito, discriminação, hostilidade e exploração (Bógus e Fabiano, 2015: 132-134). Determinados setores da sociedade brasileira encaram com desconfiança a política de recepção desses contingentes. Fazem-no, geralmente, à base de argumentos como a escassez de oportunidades e de recursos para a satisfação das demandas dos próprios brasileiros e em nome da suposta proteção da cultura e dos valores nacionais (Santin, 2007: 151).

Reações dessa ordem costumam dissimular preconceitos inconfessáveis, derivados, por definição, da ignorância (medo do desconhecido) e da carência de alteridade, caracterizada pela dificuldade ou pela recusa de enxergar-se-no-outro, compreendê-lo e colocar-se-em-seu-lugar. Problemas de idêntica ou semelhante natureza também recaem sobre todos os demais segmentos minoritários da sociedade e derivam, basicamente, das mesmas causas. Por conseguinte, parece claro que essa recepção de contingentes estrangeiros não se processa sem suscitar determinados conflitos e impor desafios em campos diversificados, como saúde pública e mercado de trabalho, a exigir o desenvolvimento de políticas públicas específicas para equacionar as tensões derivadas desse processo de deslocamento humano.

\section{Para fechar -e abrir- o círculo: o multiculturalismo e o trabalho, um encontro inevitável (e desafiador)}

No capítulo inaugural, tratou-se da interação reflexiva entre o trabalho e a democracia. Na sequência, cuidou-se de descrever o processo evolutivo de formação da sociedade brasileira com a ênfase na contribuição dos traços de multiculturalidade que assinalam a identidade genética do Estado Democrático de Direito fundado pela Constituição Federal de 1988, com a colocação do problema da contínua - e crescente - correlação dialética entre o multiculturalismo e democracia, diante de novos - e de velhos - desafios. No presente segmento, fecha-se o círculo, com a retomada do seu ponto de partida: o trabalho, inserido, agora, nesse específico contexto do multiculturalismo. O fechamento circular, contudo, não se opera de modo estático nem hermético: trabalho, democracia e multiculturalismo prosseguem, em moto-contínuo, no processo dinâmico de interação dialética e abertura funcional. Neste ponto, portanto, o círculo fecha-se, metodologicamente, para, na sequência, de modo coeso, abrir-se sobre o objeto específico da pesquisa: a proteção do direito de liberdade religiosa de grupos minoritários.

No Estado Democrático de Direito marcado pelo multiculturalismo, os grupos minoritários tendem a exercer crescente protagonismo em dupla dimensão: a) quantitativa, pois, esses segmentos da sociedade passam a contar com contingentes mais expressivos de pessoas em razão do ambiente social e institucional um pouco mais amistoso e favorável, o que torna possível a assunção mais explícita das condições de identificação desses grupos, que, no passado, tendiam a permanecer reprimidos; assim, as pessoas pertencentes a esses grupos emancipam-se, tornam-se, por assim dizer, socialmente mais visíveis e, por consequência, passam a ocupar espaços sociais anteriormente pouco acessíveis; e b) qualitativa, como resultado dialético da articulação social desses grupos em movimentos de afirmação, reconhecimento e reivindicação de direitos com o progressivo fortalecimento do sistema jurídico de proteção desses grupos.

O crescimento quantitativo e qualitativo da participação dos grupos minoritários aparece, com relevante destaque, no campo do trabalho, o que demonstra e, mais do que isso, reforça a centralidade desse espaço na sociedade, como elemento primordial para o desenvolvimento. $\mathrm{O}$ exemplo histórico mais representativo dessa mudança estrutural no mercado encontra-se na emancipação feminina e na chegada massiva de mulheres a ambientes outrora reservados à 
população masculina (Barbosa, 2014: 1-2). Com o avanço do processo de democratização do Estado e da sociedade, outros grupos minoritários passam a conquistar acesso a esse ambiente.

Historicamente, a relação entre trabalho e capital carrega pronunciados traços de ambivalência. Evidencia-se permanente estado de tensão: por vezes mais discreto, em situação de latência; por vezes mais evidente, em momentos de greve, por exemplo. Os objetivos de um de outro são, na essência, divergentes. No entanto, a despeito dessa inerente tensão, trabalho e capital são mutuamente dependentes. O desenvolvimento de um depende, em enorme medida, do desenvolvimento do outro, em conjugação sinérgica. De forma bem resumida: para a classe trabalhadora, se não há quem dê trabalho, não há salário do qual se possa extrair o sustento; para o capital, se não há quem trabalhe, não há lucro. Cuida-se, portanto, de delicado equilíbrio de forças sociais antagônicas.

A chegada mais expressiva de grupos minoritários ao ambiente trabalho acentua e incrementa o estado de tensão. Acentua, porque a empresa obriga-se a incorporar ao processo produtivo elementos representativos da diversidade humana, com a vedação jurídica de tratamento discriminatório e até mesmo com a imposição de adoção de medidas de compensação resultantes de políticas públicas de ação afirmativa, como no exemplo da reserva de vagas para pessoas com deficiência. E incrementa, pois a crescente convivência com elementos de diversidade pode produzir conflitos internos na própria classe trabalhadora. Nesse caso, atribui-se à empresa o dever jurídico de propiciar ambiente de trabalho plural e harmônico mediante a realização de mediação eficiente desses conflitos, o que, por sua vez, pode recrudescer aquele estado de tensão primordial.

No entanto, de forma aparentemente paradoxal, o crescente ingresso de elementos de multiculturalidade no ambiente de inerente ambivalência conflitiva do mundo do trabalho apresenta a tendência de promover a democratização interna desse espaço. Não há, porém, autêntico paradoxo. Com efeito, a democratização das relações sociais não se põe como um produto acabado. Ao contrário: consiste em processo de gradual evolução que se constrói precisamente a partir da progressiva solução de tensões, conflitos, contradições e problemas. A contínua convivência de diferentes, em ambiente plural, apesar dessas contradições, permite a evolução: dos problemas, extraem-se as soluções.

Nesse ponto, portanto, reside mais uma demonstração de ambivalência do trabalho: por um lado, revela-se como espaço vocacionado para a produção de tensões e conflitos e, por outro, ao mesmo tempo, também ocupa papel relevante como ambiente privilegiado para 0 equacionamento desses embates, o que, mais uma vez, reforça a sua condição de centralidade na vida em sociedade e para o desenvolvimento.

\section{Os grupos religiosos minoritários no Brasil: o estado atual e as tendências}

A Igreja Católica Apostólica Romana desfrutou de condição hegemônica ao longo da experiência histórica brasileira (Bohn, 2013: 13-14). Ela continua a reunir o maior número de adeptos no país, embora apresente tendência de redução ${ }^{2}$. O número de praticantes de outras

\footnotetext{
${ }^{2}$ Chegou a ser a religião oficial do Estado, no período do Império (artigo $5^{\circ}$ da Constituição de 1824 , com o reforço decorrente dos artigos 103, 106 e 141), até que a Constituição Federal de 1891 (artigo 11, § $2^{\circ}$ ) viesse a estabelecer a laicidade, regime que se repetiu nos demais documentos constitucionais da República. Em 2000, congregava por volta de $74 \%$ da população (com cerca de 125 milhões de praticantes no universo de aproximadamente 170 milhões
} 
religiões expandiu-se, com destaque para as igrejas evangélicas pentecostais e neopentecostais, com salto de cerca de $10 \%$ para aproximadamente $13 \%$ da população (crescimento relativo por volta de $30 \%$ ). A população islâmica também aumentou, embora continue a apresentar diminutos números absolutos: passou de 27.239, em 2000, para 35.167, em 2010, com, expansão, portanto, de aproximadamente $29 \%$ (bem superior à taxa de crescimento da população total nesse mesmo período, que não chegou a 13\%). Também se verificou significativa expansão relativa das tradições religiosas indígenas, com progressão de 17.088 para 63.082 no período em referência. (IBGE, 2010).

Houve crescimento mais modesto das pessoas que se declaram sem religião, incluindo, nesse segmento, ateus e agnósticos: aumento de 12.492.403, em 2000 (por volta de 7,4\% da população), para 15.335.510 de pessoas, em 2010 (aproximadamente 8\% da população). Em contrapartida, a proporção dos praticantes da umbanda, do candomblé e de outras manifestações de religiosidades afro-brasileiras manteve-se estável no período de 2000 a 2010, com cerca 0,3\% da população (pouco mais de meio milhão de praticantes) (IBGE, 2010).

Um conjunto convergente e dialógico de fatores fornece indícios razoavelmente seguros de que a tendência de crescimento dos grupos religiosos minoritários deve manter-se ou até mesmo ampliar-se no próximo censo demográfico, com realização prevista para 2020. Em primeiro lugar, tem-se a chegada mais expressiva de contingentes de imigrantes e refugiados vindos de lugares os mais diversos, com crenças religiosas e visões cosmogônicas próprias. É o caso, para exemplificar, de pessoas oriundas de países de tradição islâmica (Síria, como exemplo recente). Como outro exemplo, mencione-se o Haiti, país com presença de grupo minoritário de praticantes de culto a espíritos ancestrais (vuduísmo, vodou).

Em segundo lugar, de um modo mais geral, a questão do multiculturalismo, com a proteção dos direitos dos grupos minoritários, passou a importar e a ganhar maior relevância, visibilidade e reconhecimento nos espaços públicos de discussão: o enfrentamento da questão, sob diversificadas perspectivas e recortes, entrou na agenda do debate institucional nas instâncias de poder formal (discussões legislativas, por exemplo) e no ambiente acadêmico, com produção de pesquisas em diversos campos do conhecimento.

Para demonstrar esse ponto, mencione-se, como exemplo, o Estatuto da Igualdade Racial (Lei $\mathrm{n}^{\circ}$ 12.288, de 2010), que assegura «à população negra a efetivação da igualdade de oportunidades, a defesa dos direitos étnicos individuais, coletivos e difusos e o combate à discriminação e às demais formas de intolerância étnica», inclusive no campo das manifestações religiosas, passou a viger em meados de outubro de 2010, de sorte que os seus efeitos concretos não podiam captar-se no censo demográfico daquele ano, mas que, passada uma década, tendem a refletir esses efeitos também quanto à afirmação da identidade religiosa desse segmento da população.

Como consequência direta dessa agenda, observam-se avanços no processo de construção e afirmação de identidades das pessoas que integram os grupos minoritários (não apenas religiosos, mas com a produção de efeitos nesse campo). Em compasso lento, o ambiente social tende a tornar-se menos hostil à presença ostensiva dos grupos minoritários. Os atos de discriminação ainda são abundantes e corriqueiros, mas podem notar-se avanços: progressivamente, a violência

habitantes); dez anos depois, o contingente recuou significativamente e passou para cerca de $65 \%$ : na casa de 123 milhões de adeptos entre aproximadamente 190 milhões de habitantes (IBGE, 2010). 
- real e simbólica - deixa de ser «normalizada» como outrora e, cada vez mais, a sociedade passa a não tolerar os intolerantes.

Em terceiro lugar, o processo descrito no ponto anterior, impulsiona-se pela crescente expansão dos meios de comunicação de massa menos verticalizados - mais democráticos, portanto -, sediados, sobretudo, na rede mundial de computadores, que permitem o encurtamento de espaços para o encontro de pessoas ligadas por traços de identidade (religiosa, inclusive). Os encontros convergentes nesse tipo de ambiente mais horizontal permitem o compartilhamento de ideias e vivências e facilitam a identificação dos problemas mais recorrentes do grupo e, por conseguinte, a construção coletiva de soluções adequadas, com a articulação das ações necessárias para colocá-las em prática.

Em quarto lugar, observa-se o paulatino fortalecimento do sistema orgânico de proteção dos direitos dos grupos minoritários e de combate aos atos de discriminação praticados contra eles (inclusive grupos religiosos), com atuação crescente e mais efetiva do aparato institucional de repressão a esse tipo de comportamento. Nesse campo, destaca-se a atuação do Judiciário, do Ministério Público, da Defensoria Pública e de diversos órgãos de proteção aos direitos humanos em âmbito municipal, estadual e federal. Por exemplo, em abril de 2018, no julgamento de recurso em ação civil pública, o Tribunal Regional Federal da Terceira Região manteve a condenação de duas emissoras de televisão aberta para concederem amplo direito de resposta a entidades representativas de religiões afro-brasileiras em razão da exibição de programas em que se retrataram essas religiões a partir de perspectiva distorcida e preconceituosa (Brasil, 2018).

Da interação reflexiva de todos esses fatores, portanto, pode prognosticar-se a expansão quantitativa e até mesmo qualitativa dos segmentos religiosos minoritários no Brasil. Esse crescimento repercute no campo das relações de trabalho, como, aliás, se dá em relação a numerosas outras interfaces entre trabalho e multiculturalismo, e não apenas no terreno da religião.

\section{O direito fundamental de liberdade religiosa e a autonomia privada existencial da pessoa do trabalhador}

Como se quis demonstrar em capítulo próprio, o campo do trabalho consubstancia-se no espaço dotado de centralidade e assinala-se pela presença de camadas de relações sociais tensionadas e potencialmente conflituosas, especialmente no ambiente do Estado Democrático de Direito, que propicia o afloramento desse tipo de impasse. Em regimes autocráticos, os conflitos decorrentes do encontro de forças sociais contrapostas permanecem silenciados: existem, porém não encontram canal de extravasamento.

Nesse sentido, portanto, a democracia revela-se conflituosa por excelência e por definição: trata-se de espaço de convivência de contrários e de solução institucionalizada de conflitos que ela própria permite surgir, inclusive nos domínios das relações privadas de trabalho.

$\mathrm{Na}$ ordem jurídica brasileira, a relação de trabalho típica assume a forma de contrato estruturado pelo regime de subordinação (artigos 442 e 444 da Consolidação das Leis do Trabalho). Trata-se de relação acentuadamente assimétrica, com forte desigualdade de posições entre os seus protagonistas, sobretudo em razão da característica comumente encontrada nesse tipo de arranjo contratual: como regra, a pessoa do trabalhador depende economicamente do trabalho como a fonte única para a satisfação das suas mais elementares necessidades. 
Esse traço de distinção da relação de trabalho recomenda, justifica -e, mais do que isso, determina- a instituição de mecanismos de regulação do tipo forte, de matriz predominantemente heterônoma, com severa limitação do campo de autonomia privada contratual dos agentes econômicos envolvidos (empresa e trabalhador). Com isso, a ordem jurídica assume o propósito de suavizar a assimetria ontológica de posições. Ameniza, mas não elimina. Em primeiro lugar, porque a dependência econômica da pessoa do trabalhador subsiste como dado inamovível da realidade (Oliveira, 2012: 131-132). Em segundo lugar, pois a própria ordem jurídica trabalhista desenha o figurino estrutural da relação sob o signo da subordinação, com a previsão normativa de um feixe consideravelmente amplo de poderes para o empregador.

$\mathrm{Na}$ configuração da relação jurídica de trabalho, divisa-se dupla dimensão da autonomia privada: patrimonial e existencial. No plano concreto, na fisiologia da execução do contrato de trabalho, porém, nem sempre se revela possível cindir ambos os aspectos da autonomia em compartimentos atomizados, pois o programa contratual se realiza em dinâmica interativa complexa. De todo modo, a distinção assume relevância metodológica e científica.

Com efeito, na camada estrutural mais aparente, a relação de trabalho habita o campo da autonomia privada contratual, a orbitar em torno do conteúdo econômico da operação. Nesse plano, inserem-se as obrigações elementares do contrato, de caráter correlativo, como decorrência da bilateralidade desse tipo de relação jurídica. De modo resumido, à obrigação do trabalhador de colocar-se à disposição do empregador para a prestação de trabalho corresponde o direito de receber a respectiva remuneração. $\mathrm{Na}$ mesma linha, à obrigação da empresa de pagar a remuneração ao empregado corresponde o direito de dele exigir a prestação do trabalho contratado.

Em outro plano, menos evidente e, sob certa perspectiva epistêmica, secundário (não no sentido de menor importância), a relação jurídica de trabalho ocupa a ambiência da autonomia privada existencial, na qual se alojam os elementos relacionados à promoção dos direitos relativos à personalidade da pessoa do trabalhador. Como espaço de construção de cidadania, o trabalho desempenha papel fundamental para a afirmação da identidade do trabalhador na vida em sociedade.

Por meio do trabalho, a pessoa consegue desenvolver-se humanamente e levar adiante as suas aspirações, desejos e projetos. Esse aspecto reforça a importância da missão regulatória da ordem jurídica trabalhista, que deve modular-se no sentido de proteger as legítimas expectativas de desenvolvimento humano da pessoa do trabalhador. Em razão disso, no campo existencial, o grau de interdição da atuação da autonomia privada, sobretudo a do empregador, encontra restrições ainda mais agudas. $\mathrm{O}$ direito de liberdade religiosa insere-se nesse campo, refira-se ou não a grupos minoritários.

Em linha geral, o empregador tem o dever jurídico de abster-se de interferir no livre desenvolvimento da personalidade do trabalhador, sobretudo quanto aos elementos que exorbitam do eixo espaço-tempo da execução do contrato de trabalho. Nesse sentido, para o contrato de trabalho, como regra, são desimportantes todas as formas de expressão e ação da pessoa do trabalhador: a) fora do local de trabalho (eixo espacial) e b) para além dos limites da jornada de trabalho (eixo temporal). Trata-se de expressão concreta do direito fundamental à intimidade e à vida privada da pessoa do trabalhador como resultado da vinculação normativa direta da Constituição Federal sobre a relação contratual de trabalho.

No entanto, os conflitos com maior recorrência no campo da liberdade de religião assomam em situações mais delicadas e, por vezes, limítrofes. Para esse tipo de caso, a simples aplicação 
da diretriz genérica de espaço-tempo não costuma conseguir fornecer respostas juridicamente adequadas para a tutela desse direito fundamental ${ }^{3}$, especialmente em relação aos grupos religiosos minoritários, mais expostos a atos de preconceito, intolerância e discriminação, condição social que os coloca em situação de maior vulnerabilidade.

\section{O direito fundamental de liberdade religiosa}

O figurino estrutural do Estado Democrático de Direito fundado pela Constituição Federal de 1988 estabelece o regime de laicidade, mediante a previsão expressa do seguinte conjunto elementar de proibições em relação a cultos religiosos e a igrejas, com abrangência sobre os três níveis de organização federativa (artigo 19, I): a) o estabelecimento de religião oficial (ou oficiosa); b) o patrocínio (incentivo financeiro ou institucional), c) a interferência na organização e funcionamento, d) a manutenção de relações de dependência ou aliança, admitindo-se, porém, os arranjos colaborativos de interesse público, como convênios para a atuação na área de assistência social, por exemplo.

Nesse ponto, o Brasil difere de países que adotam modelos teocráticos, como a República Islâmica do Irã (artigo 12 da Constituição de 1979, dentre outros) ou de Estados que conservam relações oficiais mais próximas com determinada corrente religiosa hegemônica, como a Argentina, em relação à Igreja Católica (artigo $2^{\circ}$ da Constituição Federal de $1853^{4}$ ).

Paralelamente ao regime de laicidade, o Estado do brasileiro insere a liberdade religiosa no catálogo de direitos fundamentais, com âmbito de proteção amplo, a alcançar diversas emanações e «posições jusfundamentais» (Weingartner Neto, 2007: 72-77), a começar pelo reconhecimento da inviolabilidade de crença (artigo $5^{\circ}, \mathrm{VI}$ ), com alcance positivo (liberdade de crer) e negativo (liberdade de não crer). $\mathrm{O}$ mesmo dispositivo normativo assegura, ainda, a) a liberdade de culto e b) a proteção dos espaços em que se realizam cultos e liturgias.

No inciso seguinte, garante-se o exercício de objeção de consciência religiosas seguida da exigência de contrapartida mediante o cumprimento de prestação alternativa prevista em lei, impedindo-se, nesse caso, a privação de direitos. Além desses preceitos específicos, outras normas constitucionais ampliam ou reforçam o espectro de proteção da liberdade religiosa, como, por exemplo, a previsão de punição a qualquer ato de discriminação violador desse direito fundamental (artigo $\left.5^{\circ}, \mathrm{XLI}\right)$.

O âmbito subjetivo da proteção ao direito fundamental de liberdade religiosa também tem alcance amplo. No plano da titularidade do direito, todas as pessoas contam com a proteção jurídica para crer ou não crer, para praticar ou não praticar determinada religião, para frequentar ou não os espaços destinados a certo culto. Evidentemente, não se cuida de direito absoluto categoria estranha à ordem jurídica brasileira. Com efeito, no campo do exercício, em caso de colisão, o direito de liberdade religiosa, sem despir-se por completo de sua normatividade, pode ter de ceder diante de outros direitos fundamentais, como resultado da aplicação de mecanismos

\footnotetext{
${ }^{3}$ De modo mais abrangente, diante das profundas transformações por que passa o mundo de trabalho na sociedade de informação («economia de plataforma» e «indústria quatro ponto zero», por exemplo), acentua-se a desconstrução e consequente ressignificação - dos elementos de tempo-espaço como classicamente conhecidos (tempo como jornada; espaço como sede da empresa; tempo-espaço como jornada cumprida na sede da empresa). Consequentemente, a aplicação desses elementos em sua versão tradicional não conta com a aptidão suficiente para resolver de modo adequado os conflitos decorrentes dessas transformações.

${ }^{4}$ «El Gobierno federal sostiene el culto católico apostólico romano».
} 
próprios para a solução desse tipo de impasse, como a concordância prática e a cedência recíproca.

No campo da sujeição passiva (identificação daqueles em face de quem se pode exigir o cumprimento de deveres e obrigações), as normas definidoras desse direito fundamental endereçam-se, primordialmente, ao Estado, como manifestação da denominada eficácia vertical. Nesse plano, o Estado deve: a) abster-se de adotar condutas que venham a comprometer o exercício desse direito fundamental em relação ao seu núcleo essencial (dimensão negativa dever de abstenção), e b) por em práticas as medidas necessárias para repelir atos de particulares que atentem contra o exercício desse direito fundamental, como, por exemplo, o dever de reprimir atos de discriminação contra os segmentos religiosos minoritários (dimensão positivadever de ação).

Trata-se, também, de comando normativo dirigido a todos os particulares, na chamada eficácia horizontal das normas definidoras desse tipo de direito. Deles se exige, juridicamente, o dever de abstenção em relação a condutas violadoras do direito de liberdade religiosa. Transgredido o dever de abstenção, o ofensor do direito obriga-se a cessar a prática ilícita e a reparar os correspondentes danos.

Por fim, nas relações assinaladas pelo desequilíbrio de posições, como se dá, tipicamente, nas relações de trabalho, em que um sujeito exerce ascendência sobre o outro, pode falar-se de eficácia diagonal das normas de direito fundamental (Contreras, 2009: 75). Nesse tipo de relação jurídica, a disparidade de condições de fato e de direito alça o empregador ao patamar de exercício de poder sobre o conjunto de trabalhadores, de forma que não se iguala, mas, em certo sentido, se assemelha àquele tipo de condição assimétrica que se verifica nas relações entre o Estado e os cidadãos. Poder, na democracia, implica responsabilidade, entendida como dever dar respostas. Cuida-se, de modo mais preciso, de poder-função, a exercer-se na forma e nos limites dos objetivos justificadores da sua existência.

Nesse sentido, a similitude da forma de exercício do poder-função justifica que ao empregador se imponham deveres jurídicos mais amplos do que aqueles a que se sujeitam os particulares em geral. Por conseguinte, a eficácia diagonal das normas definidoras do direito fundamental de liberdade religiosa sujeita o empregador não apenas ao dever de abstenção de condutas violadoras desse direito, como se dá em relação aos particulares em geral (dimensão negativa). Exige-se mais.

Com efeito, como desdobramento do poder-função e da função social da empresa, impõese ao empregador o dever jurídico de pôr em prática as medidas necessárias para repelir os atos de transgressão ao direito fundamental dos empregados praticados por outros empregados, clientes e fornecedores (dimensão positiva). Em caso de cumprimento deficiente desse dever, a empresa passa a arcar com a obrigação de reparar os danos decorrentes do comportamento omissivo.

\section{A liberdade religiosa e o trabalho}

No capítulo anterior, descreveu-se, brevemente, a matriz constitucional das normas definidoras do direito de fundamental de liberdade religiosa, com o registro acerca dos elementos de estruturação: seu conteúdo objetivo primordial (quid), sua titularidade (cui), e sua destinação (quis), reconhecendo-se sua aplicabilidade no campo das relações contratuais de trabalho como resultado da denominada eficácia diagonal desse tipo de direito. No capítulo que se inicia, 
incursiona-se pelos aspectos relativos ao funcionamento dinâmico do direito de liberdade religiosa no mundo do trabalho, seguindo a diretriz metodológica proposta para a realização da presente investigação científica (proteção dos grupos religiosos minoritários no contexto do multiculturalismo).

\section{1 o marco de regulação}

No plano internacional, o Pacto Internacional sobre Direitos Econômicos, Sociais e Culturais, aprovado em 1966 no âmbito das Organizações Unidas ${ }^{5}$, assegura o exercício dos direitos dela decorrentes sem nenhum tipo de «discriminação por motivo de raça, cor, sexo, língua, religião, opinião política ou de outra natureza, origem nacional ou social, situação econômica, nascimento ou qualquer outra situação» (artigo $2^{\circ}$ ). $\mathrm{O}$ mesmo ato garante o «direito ao trabalho» (artigo $6^{\circ}$ ), em condições «justas e favoráveis» (artigo $7^{\circ}$ ), o que, em interpretação sistemática, deve levar em consideração a necessidade de proteção da pessoa do trabalhador em relação a todo tipo de prática discriminatória.

Em semelhante sentido, o Pacto Internacional sobre Direitos Civis e Políticos ${ }^{6}$, aprovado no mesmo ambiente institucional, contém amplo acervo de garantias para assegurar o exercício do direito de liberdade religiosa (artigos $2^{\circ}, 4^{\circ}, 18,20$ e 24 a 27, por exemplo). $\mathrm{O}$ artigo 27 do ato, em particular, volta-se à proteção específica dos membros de segmentos religiosos minoritários para assegurar a eles, como grupo, os seguintes direitos: a) desenvolverem vida cultural própria, e b) professarem e praticarem a religião.

O sistema de proteção em face de práticas de discriminação estende-se para o campo das relações de trabalho, inclusive na esfera de representação da classe trabalhadora em espaços como sindicatos, comissões de empresa e conselhos públicos, por força da aplicação do artigo 25 , «a», para esse tipo de ambiente ${ }^{7}$. Nesse específico sentido, na regulação do regime de representação dos trabalhadores perante a empresa, a Consolidação das Leis do Trabalho, após a reforma levada a efeito por meio da Lei ${ }^{\circ} 13.467$, de 2017, explicitou a proibição de adoção de práticas discriminatórias nesse espaço democrático de expressão da vontade da classe trabalhadora.

Com efeito, o artigo 510-B, V, cuida de inscrever no campo das atribuições da comissão de representantes dos empregados a tarefa de «assegurar tratamento justo e imparcial aos empregados, impedindo qualquer forma de discriminação por motivo de sexo, idade, religião, opinião política ou atuação sindical». Trata-se, portanto, de regra voltada ao controle democrático da própria atuação do órgão de representação. Esse comando apresenta rico potencial normativo. Em primeiro lugar, repele a discriminação no momento de apresentação de candidaturas de empregados a cargos na comissão (os regulamentos pertinentes não podem conter, explícita ou implicitamente, regras que limitem a participação do universo de empregados por motivos discriminatórios). E em segundo lugar, a atuação concreta da comissão não pode redundar em

\footnotetext{
${ }^{5}$ Incorporado à ordem jurídica interna por meio do Decreto no 591, de 1992.

${ }^{6}$ Incorporado à ordem jurídica interna por meio do Decreto no 592, de 1992.

7 «Todo cidadão terá o direito e a possibilidade, sem qualquer das formas de discriminação mencionadas no artigo 2 e sem restrições infundadas: a) de participar da condução dos assuntos públicos, diretamente ou por meio de representantes livremente escolhidos; $(\ldots) »$.
} 
discriminação quanto aos grupos minoritários coletivamente considerados ou em relação às pessoas que os integram.

Nesse sentido, os atos concretos relacionados ao funcionamento da comissão, como, por exemplo, o conteúdo da pauta de reivindicação de direitos perante a empresa, não podem exercerse de modo a excluir determinados segmentos minoritários na empresa ou na sociedade como um todo, ou a tratá-los de maneira desvantajosa em relação aos demais trabalhadores e grupos majoritários. Cuida-se, assim, de mecanismo de controle democrático da política de atuação da comissão. De semelhante maneira, essas diretrizes devem aplicar-se na atuação das entidades sindicais de qualquer grau. Ou seja, para arrematar, as diretrizes de governança do funcionamento desses órgãos de representação dos trabalhadores devem incorporar mecanismos de promoção da multiculturalidade, inclusive em relação aos segmentos religiosos minoritários.

$\mathrm{Na}$ sequência da descrição do marco de regulação de proteção jurídica dos grupos religiosos minoritários no ambiente de trabalho, ainda no plano internacional, tem-se corpo normativo específico, constante da Convenção no 111 , de 1958, da Organização Internacional do Trabalho - OIT, referente à «discriminação em matéria de emprego e profissão» ${ }^{8}$, com previsão expressa acerca da proibição de adoção de práticas discriminatórias por motivo de religião (artigo $\left.1^{\circ}, 1, \ll \mathrm{a} »\right)$.

$\mathrm{Na}$ ordem jurídica interna, a proteção das minorias religiosas no campo das relações de trabalho toma como ponto de partida a Constituição Federal, com um sistema normativo complexo e dinâmico de proteção dos direitos desses segmentos, a começar pela consagração dos objetivos de construção de «sociedade livre, justa e solidária» (artigo $3^{\circ}$, I) e de promoção do «bem de todos» sem nenhum tipo de discriminação (artigo $3^{\circ}$, IV). Um pouco antes disso, o próprio preâmbulo da Constituição - a despeito da carência de força normativa, mas com forte apelo simbólico - menciona que o Estado Democrático por ela instituído destina-se «a assegurar o exercício dos direitos sociais e individuais, a liberdade, a segurança, o bem-estar, o desenvolvimento, a igualdade e a justiça» elevados à condição de «valores supremos de uma sociedade fraterna, pluralista e sem preconceitos, fundada na harmonia social».

No plano constitucional, a proteção desses grupos minoritários adensa-se pela previsão de amplo catálogo de direitos fundamentais, com aplicação sobre as relações contratuais de trabalho (eficácia diagonal), na forma enunciada em passagem própria da presente investigação, com particular destaque para o mandamento endereçado ao legislador ordinário quanto à previsão legal de punição a «qualquer discriminação atentatória dos direitos e liberdades fundamentais» (artigo $\left.5^{\circ}, \mathrm{XLI}\right)$.

No âmbito da ordem jurídica trabalhista infraconstitucional, merece realce a Lei $\mathrm{n}^{\circ}$ 9.029, de 1995, que desempenha a função de «lei geral antidiscriminação nas relações de trabalho»e conta com imenso potencial normativo para ajudar a dar concretude ao projeto constitucional de (re)construção desse tipo de relação jurídica em bases democráticas. $\mathrm{O}$ ato normativo não chega a mencionar, expressamente, a proibição da adoção de práticas discriminatórias fundadas em motivo religioso. O silêncio, porém, não significa que esse tipo de fundamento ocupe o campo da licitude e escape ao espectro de aplicação das prescrições constantes desse instrumento. Com acertada razão, o artigo primeiro da lei em referência contém cláusula de abertura típica

\footnotetext{
${ }^{8}$ Incorporado à ordem jurídica interna por meio do Decreto $\mathrm{n}^{\circ} 62.150$, de 1968 , com posicionamento hierárquico supralegal, normativamente encartado em patamar intermediário entre a Constituição Federal e a legislação ordinária, por cuidar-se de ato normativo sobre direitos humanos (Cartaxo e Gomes, 2016: 15).
} 
suficientemente ancha para alcançar um sem-número de situações não expressamente registradas no texto legislativo: «entre outros (motivos para a adoção de prática discriminatória e limitativa para efeito de acesso à relação de trabalho, ou de sua manutenção)».

Nesses «outros motivos», encaixa-se, sem dúvida alguma, a situação de discriminação com fundamento na religião praticada pelo trabalhador ou em decorrência de atos e práticas próprias de determinado segmento religioso. Com mais forte razão, dada a situação de maior vulnerabilidade social e jurídica, a proteção normativa alberga os grupos religiosos minoritários.

No contexto mais amplo da globalização e do processo de migração a ela associado ou não, a Lei $n^{\circ} 13.445$, de 2017, assegura que não se impedirá o ingresso de ninguém, no Brasil, «por motivo de raça, religião, nacionalidade, pertinência a grupo social ou opinião política» (artigo 45, parágrafo único). Por questão de ordem lógica, esses mesmos motivos também não podem afetar a permanência da pessoa estrangeira no país. Ademais, a política brasileira de migração adota como princípios e diretrizes, em favor do migrante, além de outras, a prevenção e a repressão a todo tipo de discriminação, como racismo e xenofobia (artigo $3^{\circ}$, II), a «igualdade de tratamento e de oportunidade» (artigo $3^{\circ}$, IX) e o «acesso igualitário e livre» a trabalho (artigo $3^{\circ}$, XI). Por «igualitário», deve compreender-se, logicamente, a possibilidade de acesso a trabalho sem barreiras fundadas em preconceito de religião. Por conseguinte, não apenas o acesso, mas também a permanência dessas pessoas no trabalho deve orientar-se por idêntico comando.

$\mathrm{O}$ artigo $4^{\circ}$ da Lei de Migração assegura para a pessoa migrante, no Brasil, extenso acervo de direitos «em condição de igualdade com os nacionais», ponto que reforça a proscrição de toda prática de discriminação. Muitos desses direitos relacionam-se, direta ou indiretamente, ao mercado de trabalho, com abrangência sobre garantias para acessá-lo e nele permanecer em bases equânimes. De forma ampla, assegura-se ao migrante o respeito aos «direitos e liberdades civis, sociais, culturais e econômicos» (inciso I), com inclusão, portanto, do direito fundamental de liberdade religiosa. A norma definidora desse direito tem eficácia inclusive no campo das relações contratuais de trabalho (eficácia diagonal) e deve servir como vetor de interpretação para os outros direitos previstos em favor do migrante.

Ademais, no próprio artigo $4^{\circ}$ do ato normativo, em matéria mais intimamente relacionada ao mundo do trabalho, garante-se, para a pessoa migrante, o direito de associação sindical (inciso VII) e o «cumprimento de obrigações legais e contratuais trabalhistas», com a «aplicação das normas de proteção ao trabalhador, sem discriminação em razão da nacionalidade e da condição migratória» (inciso XI). Esse preceito consiste em norma de extensão subjetiva de toda a ordem jurídica trabalhista brasileira para o migrante (Lima, 2015: 349), com a inclusão, portanto, do sistema de proteção contra prática discriminatórias em matéria de trabalho e emprego (aplicação da Lei $\mathrm{n}^{\mathrm{o}}$ 9.029, de 1995, por exemplo), a alcançar, assim, todos os grupos religiosos minoritários.

Além disso, a concretização desses princípios e direitos demanda a formulação e adoção de políticas públicas para fomentar a inclusão dos imigrantes no processo produtivo nacional (artigo $\left.3^{\circ}, \mathrm{X}\right)$, sobretudo em períodos de «crises migratórias», como se deu, em passado recente, em relação a expressivos conjuntos de pessoas vindas do Haiti e, mais recentemente ainda, quanto aos contingentes oriundos da Venezuela, inclusive com a necessidade de previsão de distribuição equitativa dos ônus decorrentes dessa incorporação humanitária entre as entidades federativas brasileiras, como manifestação concreta do federalismo do tipo cooperativo.

Em relação ao segmento da população brasileira com ascendência africana, o Estatuto da Igualdade Racial (Lei 12.288, de 2010) conta com sistema de proteção de direitos referentes ao 
trabalho (artigos 38 a 42) e à liberdade de religião (artigos 23 a 26, principalmente). Por conseguinte, para as pessoas que integram esse grupo, a proteção alcança ampla zona de convergência entre ambos os campos, a implementar-se, inclusive, por meio de políticas públicas de ação afirmativa (artigos $4^{\circ}$, VII, e parágrafo único). Especificamente quanto às expressões de religiosidade, $\mathrm{o}$ ato normativo apresenta a aptidão para proteger as manifestações tradicionalmente cultivadas, sobretudo, pela população negra brasileira, como o candomblé e a umbanda ${ }^{9}$. Consequentemente, as pessoas e grupos que seguem essas tradições desfrutam de amparo jurídico no campo das relações contratuais de trabalho, que os colocam a salvo de práticas de discriminação, na forma exposta ao longo da presente investigação científica.

No campo criminal, o atingimento de direitos de grupos religiosos minoritários no mundo do trabalho encontra proteção mediante o estabelecimento de normas para: a) qualificar o crime de injúria (artigo 140, $\S 3^{\circ}$, do Código Penal, com o tipo de «injúria preconceituosa», com pena de reclusão de um a três anos e multa), b) aumentar a pena do delito de «redução de pessoa à condição análoga a de escravo» (artigo 149, § $2^{\circ}$, II, com acréscimo de metade da pena básica), c) punir os crimes de «ultraje a culto e impedimento ou perturbação de ato a ele relativo» (artigo 208) e d) tipificar e reprimir os delitos «resultantes de discriminação ou preconceito de raça, cor, etnia, religião ou procedência nacional» (definidos pela Lei n ${ }^{\circ} 7.716$, de 1989), com a previsão de algumas formas típicas estritamente conectadas com o mercado de trabalho, como a «negativa de emprego em empresa» (artigo $4^{\circ}$, com pena de reclusão de dois a cinco anos), que, eventualmente, pode produzir como consequência jurídica «a suspensão do funcionamento do estabelecimento particular por prazo não superior a três meses» (artigo 16).

Por fim, ainda em relação à intolerância religiosa, a Lei no 11.635 , de 2017, estabelece 21 de janeiro como o «Dia Nacional de Combate à Intolerância Religiosa», medida com relevante valor simbólico e que pode dar fundamento para a realização de campanhas públicas e privadas dirigidas à conscientização sobre a necessidade de acolhimento de elementos de multiculturalidade religiosa no campo das relações de trabalho.

\subsection{As mais encontradiças tensões}

No campo das relações de trabalho, o exercício do direito fundamental de liberdade religiosa dos grupos minoritários pode envolver-se, basicamente, em dois eixos de conflito. O primeiro segmento, mais corriqueiro e chamativo, preenche-se pelas condutas de discriminação fundadas no simples pertencimento a grupo religioso minoritário ou decorrente de determinadas práticas observadas por adeptos desses grupos, como o uso de específicas peças de vestuário (as vestes femininas islâmicas, por exemplo) ou o porte ostensivo de objetos representativos da crença religiosa, como amuletos e guias de contas, para proteção espiritual. Nesse campo, o problema não se circunscreve ao sistema de proteção do direito de liberdade religiosa. Envolve, também, outro direito fundamental: a igualdade ou, de modo mais específico, o direito fundamental de não receber tratamento discriminatório.

O segundo bloco ocupa-se pelo conjunto de conflitos práticos do exercício de liberdade religiosa no contexto da execução da relação contratual de trabalho a abranger, por exemplo, a observância de determinados períodos de guarda e a prática de certos atos prescritos pelo corpo

\footnotetext{
${ }^{9}$ Por exemplo, o artigo $1^{\circ}$ da Lei $\mathrm{n}^{\circ}$ 12.644, de 2012, instituiu o «Dia Nacional da Umbanda», comemorado, anualmente, em quinze de novembro.
} 
normativo religioso, como a realização de orações periódicas e o cumprimento de ritos específicos para alimentação.

Note-se que o segundo grupo de situações de conflitos não se confunde com o primeiro. Com efeito, os atos correspondentes ao segundo segmento não se enquadram, necessariamente, como situações de discriminação. Cuida-se, a princípio, de problema de compatibilização da manifestação religiosa com a execução do contrato. Pode haver a interdição de certa prática religiosa no ambiente de trabalho razoavelmente justificada na situação concreta, sem que isso, por si só, evidencie discriminação.

No entanto, esses mesmos atos podem, sim, constituir, autonomamente, objeto de práticas de discriminação, como acima se apontou, ou, diante da situação concreta de tensão, vir a desencadear a prática de atos de discriminação pelo empregador ou terceiros (colegas de trabalho, clientes, fornecedores e os prepostos destes dois últimos). Por exemplo: com o propósito de esquivar-se do dever de providenciar possível medida de compatibilização quanto a determinada prática religiosa ou de eximir-se de cumprir o dever de propiciar ambiente de trabalho isento de preconceitos, o empregador pode sentir-se tentado a adotar a política discriminatória de não admitir adeptos de grupos minoritários que a adotam.

\section{3 as práticas de discriminação}

Os atos de discriminação contra grupos religiosos minoritários podem assumir conformação diversificada (Brasil, 2016: 30-33) e atingem não apenas o direito fundamental de liberdade religiosa, mas também o direito à igualdade material (na específica vertente do direito fundamental de não receber tratamento discriminatório). Quanto ao momento da prática da conduta discriminatória, o ato pode ocorrer em todas as fases do ciclo da relação de trabalho. Em primeiro lugar, a discriminação pode ocorrer na fase pré-contratual e concretizar-se pela negativa de acesso à conclusão do contrato de trabalho em razão do pertencimento a determinado grupo religioso.

Como regra, a identificação concreta de práticas discriminatórias no trabalho cerca-se de dificuldades, Com o intuito de evitar as consequências jurídicas e sociais decorrentes do comportamento ilícito, o empregador tende a adotar as cautelas necessárias para tentar dissimular a prática discriminatória e dar ares de neutralidade e normalidade a esses atos, na denominada discriminação indireta. Na fase pré-contratual o problema se intensifica, pois a ordem jurídica trabalhista brasileira não exige, de forma expressa, a fundamentação da negativa de acesso a emprego em processos de seleção. Nesse sentido, para acobertar todo tipo de prática discriminatória em processos dessa natureza, o empregador costuma valer-se do artifício de justificar a desclassificação de candidatos com motivação dotada de elevado grau de generalidade, com fundamentos do tipo «o candidato não atende o perfil desejado pela empresa», sem a adição de detalhes mais elucidativos que permitam o exercício de controle do ato no âmbito administrativo e judicial.

No entanto, determinados elementos podem indicar a ocorrência de atos de discriminação nessa etapa preliminar, como a formulação de perguntas sobre religião no curso de entrevista de emprego ou em formulários para inscrição em processo seletivo ou, ainda, mediante a exigência de inclusão desse tipo de informação em currículo. Em terreno fronteiriço com a liberdade religiosa, pode configurar-se pela a exigência de apresentação de «mapa astral» ou do afastamento de postulantes nascidos sob determinados signos astrológicos. 
Além disso, para a detecção de atos de discriminação indireta, podem aplicar-se métodos de rastreamento mais sofisticados, mediante o controle da política de contratação da empresa com base na teoria do impacto desproporcional dos atos aparentemente neutros de seleção de pessoal, mas, que na essência, ainda que não intencionalmente, acabam por segregar determinados segmentos da sociedade, como os grupos religiosos minoritários, e tornam o ambiente de trabalho pouco diverso e fechado à multiculturalidade (Peresie, 2009: 776). Para essa avaliação, usam-se, por exemplo, ferramentas de estatística para avaliar a proporção de determinado segmento social nos quadros da empresa em comparação com a participação desse mesmo grupo na sociedade como um todo (Lima, 2010: 287-288). Nesse caso, a identificação de disparidades de representação pode revelar indícios da adoção de práticas de discriminação e justificar a aplicação de medidas de correção.

Em caráter excepcional, a negativa de acesso a emprego por motivo religioso pode encontrar justificativa jurídica plausível e, portanto, não se enquadrar como discriminação. Por exemplo, uma empresa que se dedica ao preparo e fornecimento de refeições para os frequentadores de um clube exclusivamente aos sábados pode deixar de contratar um garçom ou cozinheiro praticante de religião que exige a guarda desse dia. Em rigor, nesse tipo de caso, o motivo determinante para a negativa de acesso ao emprego não reside, propriamente, na religião (deixar de contratar porque a pessoa segue determinada religião), mas na impossibilidade prática de satisfação da demanda do empregador.

De semelhante maneira, a admissão preferencial ou exclusiva de empregado praticamente de determinada religião pode encontrar fundamento jurídico razoável e não caracterizar prática discriminatória em relação às pessoas pertencentes a outros grupos religiosos. Exemplo desse tipo de situação encontra-se na indústria de carnes destinadas à exportação para países de tradição islâmica, produtos que integram a classificação de «principais produtos exportados», com participação relevante nesse mercado (MDIC, 2017). Para ter acessá-lo, exige-se do exportador que a produção siga o rito previsto na lei corânica, com o abate do animal segundo o procedimento adequado a essa tradição (método halal - halāl), a efetuar-se exclusivamente por seguidor da fé muçulmana (Ribeiro, 2014: 6-9). O reconhecimento de ato de discriminação religiosa nesse contexto produziria consequências práticas danosas para os direitos da classe trabalhadora: desprotegeria, em vez de tutelar. A proibição dessa política de seleção de pessoal para a execução dessas tarefas especializadas prejudicaria a inserção da produção brasileira de carnes no mercado internacional e, por conseguinte, traria implicações mais amplas sobre o emprego nesse segmento produtivo. ${ }^{10}$

$\mathrm{O}$ ato de discriminação pode ocorrer no curso da execução da relação de emprego. De modo mais evidente, pode configurar-se pela extinção do contrato de trabalho com fundamento no pertencimento a determinado grupo religioso minoritário ou, por idêntico motivo ilegítimo, pela criação de entraves à participação do trabalhador em processos internos de ascensão funcional. Pode derivar, também, da prática de atos ou fatos relacionados ao exercício da religião (realização de orações, uso objetos e símbolos, por exemplo), ou, pelos mesmos motivos, de forma mais discreta, pela privação de acesso a determinados direitos ou ambientes, em práticas

\footnotetext{
${ }^{10}$ No âmbito do sistema de inspeção industrial e sanitária de produtos de origem animal, com fundamentos de semelhante ordem, admite-se «(...) o abate de animais de acordo com preceitos religiosos, desde que seus produtos sejam destinados total ou parcialmente ao consumo por comunidade religiosa que os requeira ou ao comércio internacional com países que façam essa exigência» (artigo 112, § $2^{\circ}$, do Decreto ${ }^{\circ}$ 9.013, de 2017).
} 
de isolamento ou segregação. Exemplos: impedir o empregado de frequentar o refeitório da empresa no mesmo horário dos colegas de trabalho; deixar de convidá-lo para eventos da empresa não relacionados a comemorações de fundo religioso.

Pode, ainda, acompanhar-se de práticas mais insidiosas, como o assédio moral (Gaudêncio e Gaudêncio, 2016: 27-28), na tentativa de levar o trabalhador à capitulação, forçando-a a tomar a iniciativa de extinguir o contrato de trabalho. Nesse particular aspecto, também pode assumir a forma de atos de escárnio da religião minoritária em si, de seus símbolos, liturgias e praticantes, individual ou coletivamente considerados, em práticas configuradoras de crime contra $o$ sentimento religioso, na forma do artigo 208 do Código Penal. ${ }^{11}$ De igual modo, pode caracterizar-se por numerosos tipos de atos de microviolência no ambiente de trabalho (Román Muñoz, 2017: 241), relacionados a representações caricaturescas da religião minoritária, mediante a atribuição de apelidos pejorativos ou a realização de comentários depreciativos a respeito do trabalhador em função de determinada prática religiosa.

Outra maneira de violação ao direito de liberdade religiosa dos grupos minoritários consiste em compelir seus adeptos a praticarem (Rivir, 2016: 81) ou a, simplesmente, presenciarem atos litúrgicos próprios da religião hegemônica ou daquela professada pelo empregador, como a determinação para acompanhar a realização de orações no curso da jornada de trabalho ou para participar de festividades de cunho religioso (Silva Neto, 2003: 124). Nesse particular, também pode configurar a violação desse direito fundamental a aplicação de sanções em razão da recusa do praticante de religião minoritária em tomar parte desse tipo evento, como o desconto de remuneração em caso de ausência, a perda de pontos para promoção por merecimento ou algum tipo de sanção disciplinar. Esse tipo de punição não passa incólume pelos filtros de condicionamento do exercício do poder disciplinar do empregador, pois carece de legitimidade e adequação. Com efeito, a recusa consiste em regular exercício do direito da pessoa do trabalhador e encontra proteção jurídica, por cuidar-se de área da autonomia privada existencial indevassável pelo empregador e, portanto, não pode abrir margem para aplicação de nenhum tipo de sanção (não se pode punir alguém pelo regular exercício de um direito).

Como se quis demonstrar em segmento próprio, em regra sujeita a exceções numericamente irrelevantes, a pessoa do trabalhador acha-se em posição de fato e de direito acentuadamente desnivelada em face do empregador. O pertencimento do trabalhador a grupos religiosos minoritários aprofunda o grau de assimetria estrutural de posições entre os protagonistas da relação de trabalho e torna os adeptos desse tipo de religião ainda mais vulneráveis a práticas discriminatórias e a condições de trabalho desvantajosas.

Em determinados casos, o grau de desigualação e de vulnerabilidade social adensa-se ainda mais em virtude da concorrência sobreposta de causas de discriminação. Nesse tipo de situação, a discriminação por motivo de religião alia-se a outros fundamentos, como procedência, etnia e gênero, na chamada discriminação múltipla (Sheppard, 2011: 3-4), dentre outros epítetos propostos pela literatura especializada, com alcance conceitual mais ou menos coincidente, como «discriminação aditiva», «combinada», «composta», «intersecional» e «sobreposta», dentre outros (Makkonen, 2002: 9-10). Nesse quadro, pode encaixar-se, por exemplo, a prática de atos

\footnotetext{
11 «Escarnecer de alguém publicamente, por motivo de crença ou função religiosa; impedir ou perturbar cerimônia ou prática de culto religioso; vilipendiar publicamente ato ou objeto de culto religioso: Pena - detenção, de um mês a um ano, ou multa. Parágrafo único - Se há emprego de violência, a pena é aumentada de um terço, sem prejuízo da correspondente à violência».
} 
de discriminação contra imigrantes muçulmanos (concurso de preconceitos em razão da procedência e da religião) ou contra mulheres negras praticantes de religiões afro-brasileiras como a umbanda e o candomblé (cumulação de preconceitos em razão do gênero, da raça e da religião).

\subsection{O exercício da liberdade religiosa e o trabalho: as possibilidades, os limites e a solução de conflitos}

Na presente seção, examinam-se situações práticas relacionadas ao exercício do direito fundamental de liberdade religiosa de grupos minoritários em interconexão com o trabalho mediante a descrição dos mais relevantes conflitos resultantes dessa interação e o apontamento de critérios para a solução adequada dessas controvérsias.

Divisam-se dois destacados grupos de interação do exercício do direito de liberdade religiosa e o trabalho. Da perspectiva da execução da relação contratual de trabalho, o primeiro segmento orienta-se, primordialmente, pelo fator tempo (quando). O segundo grupo relaciona-se mais proximamente com o elemento espaço (onde). Evidentemente, determinadas manifestações do exercício do direito fundamental em referência ocupam zonas de confluência de tempoespaço. Trata-se, assim, apenas de determinar a preponderância de certo elemento para o cumprimento de propósito metodológico, com a finalidade de facilitar a exposição dos argumentos.

No primeiro segmento (predominância do elemento tempo), inscrevem-se as interações relacionadas ao cumprimento da jornada de trabalho (com abrangência sobre os horários de começo e término de cada ciclo diário), às pausas, aos intervalos e, principalmente, aos dias consagrados ao repouso semanal. No segundo grupo de interface entre religião e trabalho (preponderância do fator espaço), inserem-se os atos concretos correspondentes ao exercício de diversas emanações do direito fundamental de liberdade religiosa na ambiência do trabalho, como o uso ou o porte de símbolos, amuletos e indumentária específica e também a prática de atos como a realização de orações e a difusão de fé e doutrina (proselitismo).

Um possível terceiro grupo de possível e aparente interação corresponderia aos atos e aos fatos representativos do exercício do direito fundamental de liberdade religiosa fora dos limites do eixo de conexão tempo-espaço da execução da relação contratual de trabalho. Esse segmento, portanto, representaria as práticas religiosas realizadas pela pessoa do trabalhador fora do local de trabalho e além dos limites da jornada de trabalho. Todas essas práticas, porém, integram grupo exorbitante: ou seja, acham-se para além da órbita da execução da relação contratual de trabalho e, nessa condição, ficam fora do alcance do círculo de poderes jurídicos decorrentes da relação de trabalho. Por conseguinte, nesse tipo de contexto de extrapolação do binômio tempo-espaço da execução do contrato de trabalho, a empresa não pode exercer nenhum tipo de ingerência sobre o exercício do direito de liberdade religiosa: não pode impor nenhuma forma de condição ou restrição. Nesse sentido, a empresa não pode, por exemplo, dar tratamento jurídico diferenciado a quem adota ou deixa de adotar, nessas condições, determinadas práticas religiosas.

\subsubsection{As tensões preponderantemente atreladas ao fator tempo («quando»)}

No grupo de interações entre trabalho e religião associadas primordialmente ao tempo da execução da relação contratual, os mais frequentes casos de tensão referentes aos grupos 
religiosos minoritários dizem respeito à coincidência entre o dia de guarda prescrito pelo corpo normativo sacro e o dia destinado ao repouso semanal remunerado. Como não poderia deixar de ser diferente, o papel hegemônico da tradição cristã no processo histórico de formação da sociedade brasileira produziu consequências na construção da ordem jurídica nacional, com reflexos no campo da regulação das relações de trabalho.

Por conseguinte, em consonância com aquela tradição religiosa dominante, a ordem jurídica trabalhista brasileira reserva o domingo como dia preferencial para o repouso hebdomadário, na forma do artigo $7^{\circ}, \mathrm{XV}$, da Constituição Federal, dos artigos 67, 385 e 386 da Consolidação das Leis do Trabalho, do artigo $1^{\circ}$ da Lei $n^{\circ} 605$, de 1949 , do $\S 1^{\circ}$ do artigo $1^{\circ}$ da Lei ${ }^{\circ}$ 11.101, de 2000, e do artigo 16 da Lei Complementar $n^{\circ} 150$, de 2015. No direito positivo, a autorização para a prestação de trabalho nesse dia continua a ser a exceção e, em razão disso, fica sujeita a regência específica, com maior grau de proteção à pessoa do trabalhador, conforme preveem, por exemplo, os artigos $67,68,227, \S 2^{\circ}, 229, \S 2^{\circ}, 249, \S 1^{\circ}, 307$ e 319 da

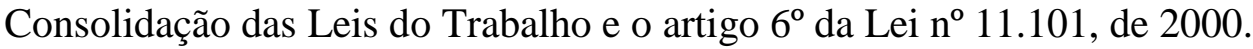

No entanto, determinados grupos religiosos minoritários presentes na sociedade brasileira observam a guarda em dia diverso do domingo, como, por exemplo, os adeptos da Igreja Adventista do Sétimo Dia e os seguidores de determinadas correntes do Judaísmo, aos sábados, e os muçulmanos, às sextas-feiras. Os dias de guarda assumem propósitos que não se limitam ao campo da manifestação religiosa: vão além para alcançar diversos aspectos de sociabilidade como a formação de vínculos comunitários e a construção de identidades, valores que também são merecedores de tutela jurídica.

Nos casos de conflito desse tipo assinalados pela normalidade, o trabalhador pertencente a esses grupos religiosos minoritários conta, a princípio, com o direito subjetivo de exigir da empresa a concessão de repouso semanal remunerado em dia coincidente com a guarda prevista no corpo normativo religioso. Para aferir a «normalidade» do caso, devem examinar-se, em concreto, de forma correlacionada: a) as necessidades produtivas decorrentes do desenvolvimento normal e regular da atividade empresarial e b) a imprescindibilidade dos serviços do trabalhador para a satisfação daquelas específicas necessidades naqueles específicos dias da semana.

As situações em que as necessidades da atividade empresarial podem prescindir dos serviços especificamente prestados pelo trabalhador pertencente a grupo religioso minoritário envolvem as tarefas que: a) o próprio trabalhador pode executar em outro dia da semana, sem gerar prejuízo à dinâmica do desenvolvimento da atividade empresarial, e b) outros trabalhadores, não integrantes do grupo religioso minoritário, podem cumprir com igual ou semelhante grau de destreza e eficiência naquelas mesmas condições (ausência de prejuízo ao curso normal da atividade empresarial). Evidentemente, a aplicação do processo de avaliação deve orientar-se, dentre outros, pelos parâmetros decorrentes do princípio da boa-fé objetiva. Ou seja, a aplicação do processo não pode servir de pretexto para encobrir atos dirigidos à frustração do exercício do direito fundamental de liberdade religiosa dos segmentos minoritários.

Por conseguinte, a aplicação concreta desses filtros de avaliação desemboca nos seguintes resultados jurídicos modalizados: a) para os casos de normalidade positiva: a empresa tem a obrigação de conceder ao trabalhador pertencente a grupo religioso minoritário o repouso semanal remunerado em dia coincidente com aquele previsto no respectivo corpo normativo religioso (com o correspondente direito subjetivo do trabalhador a usufruir o repouso nesse específico dia da semana); b) para os casos de normalidade negativa: do ponto de vista estrito da dinâmica da execução da relação contratual de trabalho, a empresa tem direito subjetivo de exigir 
do trabalhador a prestação de serviços naquele específico dia da semana (com a correspondente obrigação do trabalhador em prestar serviço naquele específico dia).

No entanto, de forma mais ampla, como se cuida de aspecto fundamental da vida da pessoa, relacionado à sua própria forma de ser e de apresentar-se em sociedade, o empregador não pode, simplesmente, obrigar o trabalhador, contra a sua vontade, em violação a sua crença, a trabalhar em dia considerado sagrado ou reservado para guarda. Nesses casos específicos, diante da impossibilidade prática de proceder à acomodação razoável ${ }^{12}$ dos interesses contrapostos do trabalhador e da empresa, ambos merecedores de atenção e tutela, a solução mais adequada para a distensão do conflito pode consistir na extinção da relação contratual de trabalho.

Por outro lado, nesse mesmo tipo de caso, não existe, em princípio, empecilho para que o trabalhador integrante de grupo religioso minoritário concorde em prestar serviços no dia da semana tradicionalmente consagrado ao repouso, por tratar-se, por exemplo, de adepto simplesmente «formal», não engajado nas práticas relativas ao grupo minoritário a que pertence (partidário não praticante), ou que verdadeiramente não se importe em deixar de observar o dia de guarda por qualquer outro motivo. O exercício desses atos abdicativos, porém, deve avaliar-se com a devida cautela, pelo mesmo motivo essencial que impede a aceitação de renúncia de direitos patrimoniais e existenciais propriamente trabalhistas, como salários e férias: a dependência econômica (na prática, a admissão de renúncia poderia levar o trabalhador a aceitar condições de trabalho gravosas ou até mesmos degradantes em razão do permanente temor de perder o posto de trabalho do qual extrai o sustento). Por consequência, para evitar o cometimento de fraudes contra os direitos decorrentes da dimensão existencial da relação contratual de trabalho, o reconhecimento da validade da prática de atos de abdicação a direitos relacionados ao repouso semanal remunerado de trabalhador pertencente a grupo religioso minoritário deve reservar-se a situações assinaladas por acentuado grau de excepcionalidade.

O tipo de conflito acima descrito pode surgir: a) contemporaneamente à constituição da relação jurídica de trabalho, solucionados com base nos critérios anteriormente delineados, ou b) no curso da execução da relação contratual, por força da ocorrência de fatos supervenientes atinentes: b1) à modificação das condições relativas às necessidades produtivas decorrentes do desenvolvimento normal e regular da atividade empresarial e b2) à pessoa do trabalhador, mediante a adesão a grupo religioso minoritário (conversão religiosa).

Para a solução das tensões derivadas de eventos adventícios, aplicam-se, na essência, aqueles mesmos critérios acima alinhavados. Cabe acrescentar, porém, algumas especificações. No caso de fato superveniente relacionado ao desenvolvimento da atividade empresarial, impõese à empresa, com maior grau de exigência, o dever de empenhar-se para providenciar as medidas de acomodação razoável que permitam ao trabalhador pertencente a grupo religioso minoritário continuar a desfrutar de repouso semanal remunerado em dia coincidente com aquele devotado à guarda religiosa, pois, em certo sentido, essa condição passa a integrar o conteúdo do contrato do trabalho. Por conseguinte, nesse cenário, os ônus impostos à empresa para a demonstração da

12 «La acomodación razonable para las prácticas religiosas en el lugar de trabajo es una técnica legal destinada a ayudar a quienes enfrentan dificultades por el hecho de tener creencias y prácticas religiosas distintas de las dominantes en el entorno. El principal objetivo de la acomodación razonable es eliminar el conflicto entre las creencias religiosas del empleado y los requerimientos organizacionales del empleador, de modo que ninguno de ellos deba sacrificar por completo sus intereses. La idea detrás de la técnica de la acomodación razonable es proveer un trato igualitario a aquellos que por un rasgo inherente (como la religión) se encuentran privados del disfrute de bienes socialmente accesibles (como el trabajo)» (Vives, 2017: 7-8). 
impossibilidade prática de fazê-lo são igualmente mais rigorosos, pois, no limite, são riscos decorrentes do empreendimento e que, portanto, correm por conta da empresa, sem a possibilidade de transferi-los, no todo ou em parte, aos trabalhadores. De mais a mais, no caso efetiva impossibilidade prática de adoção de medidas de acomodação, com a consequente solução do impasse por meio da extinção da relação contratual de trabalho, os ônus financeiros decorrentes da ruptura do contrato devem recair sobre a empresa. Na hipótese de fato superveniente relacionado à pessoa do trabalhador (adesão a grupo religioso minoritário no curso da execução do contrato de trabalho), a empresa não pode tentar eximir-se do dever de adotar as pertinentes medidas de acomodação sob a invocação de fundamento relacionado à denominada teoria dos atos próprios, em virtude da impertinência da aplicação desse corpo teórico para a extinção de posições jurídicas relacionadas ao campo da autonomia privada existencial do trabalhador. ${ }^{13}$

Os traços formativos da sociedade brasileira decorrentes da duradoura hegemonia da Igreja Católica Apostólica Romana também dão conta de explicar por que a ordem jurídica considera feriados nacionais diversos dias devotados, primordialmente, a manifestações de religiosidade cristã. Mencionem-se, como exemplo, a) o dia de finados, em dois de novembro, de acordo com o artigo $1^{\circ}$ da Lei ${ }^{\circ} 662$, de 1949, b) o Natal, em 25 de dezembro, por força do mesmo dispositivo normativo, e c) o «culto público e oficial a Nossa Senhora Aparecida, Padroeira do Brasil», em doze de outubro, conforme o artigo $1^{\circ}$ da Lei ${ }^{\circ} 6.802$, de 1980.

Além disso, em âmbito local, em razão da influência de idênticos traços de formação, fixam-se, como feriados, dias dedicados a celebrações relativas a santos padroeiros dos milhares de municípios brasileiros, na forma prevista no artigo $2^{\circ}$ da Lei $n^{\circ} 9.093$, de 1995: «São feriados religiosos os dias de guarda, declarados em lei municipal, de acordo com a tradição local e em número não superior a quatro, neste incluída a Sexta-Feira da Paixão». Em muitos municípios, por tradição, inclui-se, nesse rol de dias feriados, a quinta-feira dedicada à celebração religiosa do Corpus Christis, em data móvel segundo o calendário religioso específico.

Nos dias feriados proíbe-se, em regra, a prestação de trabalho remunerado (artigo 70 da Consolidação das Leis do Trabalho e artigo $8^{\circ}$ da Lei n ${ }^{\circ} 605$, de 1949). Quando excepcionalmente admitido (artigos 68 e 69 da CLT e artigo 10 da Lei $n^{\circ}$ 605, de 1949), produz como consequência jurídica alternativa ou o pagamento em dobro da correspondente remuneração diária ou a previsão de folga compensatória em outro dia (artigo $9^{\circ}$ ). Nas «atividades do comércio em geral», a licitude do trabalho em dias feriados depende: a) de autorização em convenção coletiva de trabalho e b) da observância dos requisitos previstos na legislação municipal, de acordo com o interesse local (artigo $6^{\circ}$-A da Lei $n^{\circ} 10.101$, de 2000).

Com as devidas adaptações, os critérios que regem a solução dos conflitos entre o direito fundamental de liberdade religiosa dos grupos minoritários e a previsão preferencial de repouso semanal remunerado aos domingos aplicam-se para a distensão concreta dos problemas relacionados aos dias devotados a celebrações religiosas específicas de cada grupo, com a observação de que, na prática, nesse campo em particular, a contraposição de interesses pode

13 Nesse sentido, por exemplo, a Primeira Turma do Tribunal Superior do Trabalho ratificou decisão que determinara, como medida de acomodação, que a Companhia Energética do Rio Grande do Norte passasse a conceder o repouso semanal remunerado «do pôr do sol de sexta-feira ao pôr do sol de sábado», período coincidente com os preceitos da religião minoritária a que o empregado aderiu depois de 28 anos de vigência do contrato de emprego (Brasil, 2015). 
produzir situações de mais difícil equacionamento, sobretudo em relação a manifestações de religiosidade que se alongam por muitos dias consecutivos.

Outros pontos de tensão relacionados ao cumprimento da jornada de trabalho podem exigir a aplicação soluções mais delicadas. Mencione-se, por exemplo, em relação aos praticantes da fé muçulmana, a necessidade de observância dos deveres religiosos concernentes ao nono mês do calendário lunar islâmico (ramadã), como o jejum ritual (Saum), que podem, em princípio, produzir reflexos na execução da relação contratual de trabalho. Além dos critérios acima apontados para a solução de conflitos, uma medida adicional tem potencial para ajudar a evitar a extinção do contrato de trabalho: a empresa, no uso da prerrogativa prevista no artigo 136 da Consolidação das Leis do Trabalho, pode fazer coincidir as férias dos trabalhadores muçulmanos com o período do ramadã. Essa medida, porém, não pode servir como instrumento para mascarar eventual prática persecutória de intolerância religiosa enquadrada como islamofobia nem como pretexto para justificar a tentativa de contornar pequenos contratempos decorrentes da adoção de medida mais suave de acomodação concretamente cabível para o caso.

\subsubsection{As tensões preponderantemente atreladas ao fator espaço («onde»)}

No segundo segmento de interconexão entre o exercício do direito fundamental de liberdade religiosa de grupos minoritários e o trabalho, relacionado, preponderantemente, ao espaço destinado à execução da relação contratual de trabalho, encaixam-se, basicamente, os atos e os fatos correspondentes: a) ao uso ou ao porte de objetos representativos de determinada crença religiosa, como símbolos, amuletos e peças de vestuário, diretamente atrelados a determinada fé, como obrigação dela decorrente (exemplo, trajes islâmicos como o $\hbar i j a ̄ b$ ou o niqāb), ou não, como, por exemplo, o uso de camiseta com estampa de motivo religioso ou conteúdo semelhante, como excertos de escritos considerados sagrados; b) a prática de atos de conteúdo religioso, como resultado do cumprimento de obrigação derivada do corpo normativo de determinada religião ou não, como, por exemplo, a realização de orações periódicas, como a salá islâmica, c) a observância de certas restrições alimentares (consumo de alimentos produzidos pelos métodos halal e kosher, por exemplo), e d) a prática de atos de difusão da fé e doutrina da religião para terceiros (proselitismo, catequização).

De início, o exame da possibilidade de exercício de determinada emanação do direito de liberdade religiosa no ambiente de trabalho deve realizar-se em concreto, mediante a análise correlacionada de circunstâncias específicas. Afere-se, assim, a presença ou a ausência de compatibilidade concreta da prática religiosa com: a) a natureza da atividade desenvolvida pela empresa; b) a função desempenhada pelo trabalhador; c) o conjunto de normas e protocolos regulamentares acerca da forma de executar determinada atividade ou tarefa (normas relacionadas, por exemplo, à higiene, à saúde e à segurança do trabalho) e d) os regulamentos da empresa, editados com base no poder diretivo, ainda que formado por atos esparsos ou sem a observância de formalidades específicas, sob a forma de «usos e costumes» da empresa, como, por exemplo, em relação à previsão de códigos de vestimenta. Examina-se, ainda, o grau de interferência concreta da prática religiosa: a) no normal desenvolvimento das atividades relacionadas à função do trabalhador na empresa, e b) na esfera dos legítimos interesses jurídicos de terceiros, como colegas de trabalho, clientes, fornecedores e correspondentes prepostos. Nesse ponto, insere-se a análise da extensão qualitativa e quantitativa dos encargos impostos à empresa para proceder à acomodação da prática religiosa, para a identificação de ônus exagerados, à 
semelhança dos institutos dos chamados encargos indevidos (undue hardship e undue burden), originariamente construídos no direito estadunidense (Leite, 2017: 3). Como resultado de juízo concreto de proporcionalidade, pode afastar-se o direito à acomodação ou torná-lo menos abrangente.

Nesse sentido, de forma bem geral, a análise da admissão do exercício de determinada prática religiosa de grupo minoritário no ambiente de trabalho deve realizar-se em função desse conjunto de fatores: formula-se juízo de compatibilidade do ato ou do fato religioso diante desses parâmetros avaliativos. Por consequência, como regra, deve admitir-se a adoção de determinada prática religiosa no ambiente de trabalho se ela alcançar avaliação positiva nesses cinco quesitos de compatibilidade.

Nesse processo avaliativo de compatibilidade, examinam-se a propriedade e a licitude do conteúdo normativo dos regulamentos da empresa mediante a aplicação dos seguintes parâmetros, orientados pela diretriz geral da função social da empresa e pelos imperativos de democratização das relações privadas: a) finalidade, b) boa-fé objetiva, c) isonomia e d) proporcionalidade. Com efeito, em relação à finalidade, o catálogo de normas do regulamento deve orientar-se para o cumprimento de propósitos lícitos e justificados, destinados a organizar a dinâmica produtiva de forma eficiente (exame de adequação funcional). Quanto à boa-fé objetiva, o regulamento não pode apresentar conteúdo que, direta ou indiretamente, resulte em discriminação das práticas religiosas dos grupos minoritários, encubra propósitos de intolerância religiosa ou sirva de instrumento para a prática de atos arbitrários ou emulativos. Por conseguinte, cabe ao regulamento tratar de forma isonômica todas as manifestações religiosas presentes no colégio de trabalhadores, sem o estabelecimento de preferências ou distinções arbitrárias. Por fim, o exame da validade de determinadas proibições ou restrições quanto a manifestações vinculadas ao direito de liberdade religiosa de grupos minoritários deve submeterse ao tríplice filtro de proporcionalidade: necessidade, adequação e razoabilidade.

Em relação ao último elemento avaliativo, concernente ao grau de interferência da prática na execução do trabalho e na esfera jurídica de terceiros, pode estabelecer-se, como padrão, sem prejuízo da avaliação dos demais quatro quesitos, o seguinte sistema esquemático de hipóteses e consequências: a) grau de interferência nulo ou zero: deve admitir-se a prática religiosa no trabalho, por cuidar-se de assunto circunscrito aos domínios da autonomia privada existencial da pessoa do trabalhador; b) quanto menor o grau de interferência, maior o grau de exigência imposto à empresa quanto ao dever de proceder à acomodação razoável da prática e, por conseguinte, c) quanto maior o grau de interferência, menor o grau de exigência imposto à empresa quanto ao dever de proceder à acomodação razoável da prática. Evidentemente, o exame desse grau de interferência não segue rígidos parâmetros matemáticos, mas resulta de construção hermenêutica, pela prudência (phrónesis).

No Estado de Democrático de Direito, com a exigência do cumprimento da função social da empresa, não se pode acolher o argumento de que o preconceito de segmentos da sociedade em relação a determinado grupo religioso minoritário pode justificar, por si só, a proibição de adoção de certa prática religiosa por ele observada sob o pretexto de que admiti-la poderia redundar em prejuízo aos negócios da empresa em razão da perda de clientes, que, por conta do preconceito, deixariam de procurar os produtos e serviços da empresa. Ainda que o preconceito exista, de fato, na sociedade, não se pode jogar o jogo dos intolerantes. A aceitação de argumentos dessa natureza, em si próprios preconceituosos e discriminatórios, viria a reforçar o preconceito presente na sociedade, em vez de combatê-lo. A construção de ambiente de trabalho 
plural, composto pelos múltiplos elementos de diversidade presentes na sociedade, cumpre, dentre outras, a função de dissipar, progressivamente, os preconceitos presentes na sociedade.

Para além de integrar o processo avaliativo da validade de normas regulamentares da empresa, a boa-fé objetiva atua como elemento de controle concreto dos atos do empregador em relação à dinâmica da execução da relação contratual de trabalho. Assim, pela aplicação prática da teoria dos atos próprios, não se admite que o empregador, sem justificativa adequada (aferida em consonância com os critérios acima delineados), passe a impor proibições ou restrições sobre determinada manifestação religiosa antes tolerada, admitida ou incentivada, por tratar-se de inovação ilícita na base contratual, na forma do artigo 468 da Consolidação das Leis do Trabalho. A recíproca, porém, não se verifica.

A adesão do trabalhador a grupo religioso minoritário no curso da execução da relação contratual de trabalho não pode consistir, por si só, em empecilho para admissão das práticas próprias dessa religião, por cuidar-se de decisão inserida no campo da autonomia privada existencial da pessoa do trabalhador. Na prática, porém, situações delicadas podem surgir, como, por exemplo, em razão de conversão a religião minoritária, o trabalhador, por imperativo da crença religiosa, não mais poder cumprir determinadas tarefas que costumava desempenhar antes da adesão. Nesse tipo de caso, como regra, subsiste, para o trabalhador, o direito de contar com medidas de acomodação revestidas de razoabilidade, com a consequente obrigação da empresa no sentido de propiciar o exercício do direito de liberdade religiosa. Como parâmetro avaliativo concreto, correlacionam-se a imprescindibilidade dos serviços especificamente prestados pelo trabalhador e as necessidades produtivas decorrentes do desenvolvimento normal e regular da atividade empresarial, de maneira semelhante com o sistema de solução de impasses referentes aos dias de guarda religiosa, descritos em seção específica. Exemplo de possível medida de acomodação: a alteração da função do empregado para o exercício de atribuições compatíveis com a nova crença religiosa. Ainda assim, em determinados casos, de acordo com a atividade econômica desenvolvida pelo empregador e conforme as especificidades do corpo normativo religioso a que o trabalhador tenha aderido, a acomodação pode revelar-se impraticável. Nesse tipo de situação extrema, como não se pode obrigar o trabalhador a desempenhar atividades por ele consideradas como violadoras da crença religiosa, o impasse pode redundar na extinção do contrato de trabalho.

Para o estabelecimento de ambiente de trabalho multicultural (e, por extensão, mais democrático), ao optarem pela reserva de lugares para a realização de atividades de natureza religiosa ou espiritual, as empresas em geral devem dar prioridade ao estabelecimento de ambientes ecumênicos (Silva Neto, 2003: 129-130) ou, ao menos, a instituição de espaços adequados para abrigar as atividades dos segmentos religiosos mais representativos da região, e isso, evidentemente, sem que se admita a adoção de práticas de discriminação ou a imposição de determinadas práticas àqueles que não costumam segui-las.

O tempo destinado às práticas religiosas, a princípio, não integra a jornada de trabalho, «por não se considerar tempo à disposição do empregador», na forma do artigo $4^{\circ}, \S 2^{\circ}$, I, da Consolidação das Leis do Trabalho. O empregador, porém, pode dispor em sentido diverso, prevalecendo, nesse caso, a aplicação da norma mais favorável ao trabalhador. 


\section{A conclusão}

Democracia, multiculturalismo e trabalho integram um círculo de convivência em permanente interação dialógica. Entre eles, opera-se contínuo movimento de circularidade dialética de propulsão recíproca e reflexiva. O Estado Democrático de Direito inaugurado pela Constituição Federal de 1988 reconhece e acolhe os traços de multiculturalidade inerentes ao processo de formação histórica da sociedade brasileira e, como sistema assinalado pela porosidade cognitiva, permanece aberto para a recepção e acolhimento de novos aportes de diversidade decorrentes do fluxo operacional do processo de globalização. Esses elementos formativos integram a identidade genética da ordem jurídica nacional e encontram-se na base estratégica de estruturação do projeto constitucional de construção de sociedade livre, justa e solidária, nacionalmente desenvolvida, sem pobreza nem marginalização e menos desigual, voltada para a promoção do bem de todas as pessoas, sem nenhum tipo de preconceito ou discriminação.

$\mathrm{Na}$ concretização do plano estratégico proposto pelo Estado Democrático de Direito brasileiro, o trabalho, de diversas maneiras, ocupa posição tática destacada e, como elemento dotado de centralidade na sociedade, atua com protagonismo nesse processo construtivo. E diante dessa condição de instrumento central, a Constituição Federal de 1988 teve o cuidado de refundar a ordem jurídica trabalhista em consonância com as bases de estruturação do novo modelo de Estado: cria-se, assim, o Direito Constitucional do Trabalho, de inspiração democrática.

Dessa maneira, diante da conjugação de premissas relacionadas à identidade genética da ordem jurídica, assentada em elementos da multiculturalidade formativa da sociedade brasileira, e ao ambiente institucional democrático, renova-se a conformação jurídica estrutural e funcional do trabalho. Ou seja, a dinâmica tradicional das relações contratuais de trabalho, centrada em elementos puramente econômicos e patrimoniais, passa, primeiramente, por processo de desconstrução para, em seguida, ressignificar-se de acordo com os influxos normativos do Estado Democrático de Direito e, com isso, incorporar elementos jurídicos de ordem existencial, para a proteção da pessoa do trabalhador.

Como consequência imediata desse novo perfil conformativo, a relação contratual de trabalho passa a reger-se por amplo acervo de normas definidoras de direitos fundamentais, como a liberdade religiosa em geral e, mais especificamente, as expressões de religiosidade dos grupos minoritários. No entanto, o ingresso mais evidente de elementos de multiculturalidade na ambiência do trabalho incrementa o estado de tensão primordial entre trabalho e capital e determina o surgimento de novos tipos de conflito.

No campo de interação do direito fundamental de liberdade religiosa dos grupos minoritários com a execução das relações contratuais de trabalho, os conflitos referem-se, basicamente, a) a práticas de discriminação, com repercussão, portanto, no direito fundamental à igualdade (direito de não receber tratamento discriminatório) e b) a atos concretos do exercício da liberdade religiosa, que podem ou não resultar de/em prática de discriminação. No tempo, os problemas concentram-se em duas etapas do ciclo contratual: a) anterior à conclusão do contrato, caracterizado pela negativa de acesso ao trabalho, e b) no curso da execução da relação contratual, redundando ou não na extinção do contrato. Nem toda interdição ou restrição de prática religiosa no tempo-espaço de execução do contrato de trabalho configura, por si só, discriminação, em razão da possibilidade de razoável justificação na situação concreta. 
Em relação às práticas discriminatórias contra os grupos religiosos minoritários, o principal desafio não reside, propriamente, na solução jurídica para o problema, que, em regra, encontra equacionamento relativamente simplificado no sistema de direito positivo (aplicação da Lei $\mathrm{n}^{\mathbf{o}}$ 9.029, de 1995, por exemplo, e uso das tutelas jurídicas de inibição e de remoção da conduta ilícita). O ponto mais desafiador, nesse campo, consiste em identificar e provar a ocorrência da prática de discriminação, pois, geralmente, atos dessa natureza realizam-se dissimuladamente (discriminação indireta). Nesse sentido, a pesquisa identificou a aplicação da teoria do impacto desproporcional, com as ferramentas a ela correspondentes, como as aferições estatísticas, como o instrumento jurídico adequado para a identificação desse tipo de prática ilícita.

Quanto aos conflitos decorrentes de atos concretos do exercício do direito fundamental de liberdade religiosa dos grupos minoritários no ambiente de trabalho, a solução mostra-se metodologicamente mais complexa. De saída, nesse ponto, a solução do problema deve realizarse em concreto, à vista dos elementos de fato em estado de tensão: ou seja, as soluções puramente dogmáticas ou meramente teóricas são más conselheiras.

Como diretriz geral, o equacionamento da tensão passa pelo exame dos eixos de espaçotempo da execução da relação contratual de trabalho: o local da prestação dos serviços e a jornada de trabalho. Desse modo, as expressões de religiosidade do trabalhador fora dos horários e do local de trabalho ocupam, com exclusividade, os domínios da autonomia privada existencial e, assim, não podem sofrer nenhum tipo de restrição ou condicionamento pela empresa. Determinados conflitos, inserem-se primordialmente no eixo de tempo (dia para repouso remunerado, pausas e intervalos). Outros, no espaço (o uso de objetos e símbolos e a prática de atos como orações e difusão de fé). De modo geral, desse tipo de conflito decorre da aplicação prática do dever jurídico de acomodação razoável dos interesses colidentes.

A solução dos conflitos relacionados ao tempo requer, basicamente, a análise de dois fatores: a) as necessidades produtivas decorrentes do desenvolvimento normal e regular da atividade empresarial e b) a imprescindibilidade dos serviços do trabalhador para a satisfação daquelas específicas necessidades naqueles específicos períodos de tempo.

Para resolver conflitos preponderantemente referenciados ao eixo espacial da execução da relação contratual de trabalho, aplicam-se, em concreto, cinco parâmetros de avaliação: a) a natureza da atividade desenvolvida pela empresa; b) a função desempenhada pelo trabalhador; c) o conjunto de normas e protocolos regulamentares acerca da forma de executar determinada atividade ou tarefa e d) os regulamentos da empresa (sujeitos a controle de legitimidade mediante a aplicação concreta de critérios de finalidade, boa-fé objetiva, isonomia e proporcionalidade) e, por fim, e) o grau de interferência concreta da prática religiosa: i) no normal desenvolvimento das atividades relacionadas à função do trabalhador na empresa e ii) na esfera dos legítimos interesses jurídicos de terceiros.

Em ambos os conjuntos de casos, a aplicação concreta dos respectivos elementos avaliativos permitirá a extração de conclusão sobre a existência ou a inexistência de direito subjetivo da pessoa do trabalhador pertencente a grupo religioso minoritário de exigir da empresa a adoção concreta de medida de acomodação razoável da prática religiosa examinada, com a correlativa identificação da existência ou da inexistência de dever jurídico da empresa de tomar as pertinentes providências referentes à acomodação razoável da prática religiosa observada pela pessoa do trabalhador integrante de grupo minoritário.

Novos estudos, com recorte mais estreitado, podem desenvolver-se mediante a aplicação desse conjunto de critérios jurídicos de avaliação sobre situações específicas de conflito 
decorrentes da interseção de determinada expressão de religiosidade de grupo minoritário com a ambiência do trabalho. Esses estudos podem consistir em exame crítico de jurisprudência sobre os casos relacionados com a matéria por meio da aplicação concreta do aparato metodológico construído na presente exposição. Nesse tipo de investigação mais vertical, mediante controle crítico da comunidade científica, as diretrizes de análise propostas no curso da presente pesquisa podem submeter-se a testes práticos de procedência, para a identificação de falhas e incongruências. Com isso, o conjunto de propostas lançado ao longo da pesquisa pode passar por processo refinamento ou revisão.

Por fim, o estabelecimento de espaços de trabalho mais plurais e ecumênicos, orientados de acordo com a habilidade de saber lidar, em termos de convivência harmônica, com os múltiplos e complexos elementos da diversidade humana, constitui elemento importante para $o$ desenvolvimento social em bases mais amplas. Nesse sentido, a construção progressiva de soluções práticas para as tensões presentes no campo concêntrico do exercício do direito fundamental de liberdade religiosa dos grupos minoritários com a execução das relações contratuais de trabalho pode contribuir para ampliar o processo de democratização do mundo do trabalho e, por consequência, da própria sociedade, como resultado positivo daquela contínua interação dialógica entre democracia, multiculturalismo e trabalho: círculo que se fecha; círculo que se abre.

\section{Referências}

Barbosa, Ana Luiza Neves de Holanda (2014). «Participação feminina no mercado de trabalho brasileiro». Boletim Mercado de Trabalho-Conjuntura e Análise, 54: 1-11. Disponível em «https://bit.ly/2O102o3».

Bavaresco, Paulo Ricardo e Daiane Paula Tacca (2016). «Multiculturalismo e diversidade cultural: uma reflexão». Unoesc \& Ciência-ACHS, 7 (1): 61-68. Disponível em «https://bit.ly/2RH3KXm».

Bógus, Lucia Maria M. e Maria Lucia Alves Fabiano (2015). «O Brasil como destino das migrações internacionais recentes: novas relações, possibilidades e desafios». Ponto-eVírgula-Revista de Ciências Sociais, 18: 126-145. Disponível em «https://bit.ly/2yvSNiv».

Bohn, Simone (2013). «Proteção às minorias religiosas no brasil». Em Liliana Lyra Jubilut, Alexandre Gustavo Melo Franco Bahia e José Luiz Quadros de Magalhães (coordenadores), Direito à diferença. v. 2: aspectos de proteção específicas às minorias e aos grupos vulneráveis. São Paulo: Saraiva.

Cartaxo, Marina Andrade e Ana Virginia Moreira Gomes (2016). «As convenções da OIT sobre a proteção aos direitos do trabalhador migrante». Revista Brasileira de Direito Internacional, 2 (2): 1-22. Disponível em «https://bit.ly/2OSqeWx».

Contreras, Sergio Gamonal (2009). «Procedimiento de tutela y eficacia diagonal de los derechos fundamentales». Revista Laboral Chilena, 19: 72-76.

Dahl, Robert (2006). A preface to democratic theory. Chicago: University of Chicago Press.

DaMatta, Roberto (1986). O que faz o brasil, Brasil? Rio da Janeiro: Rocco.

Deakin, Simon (2016). «Labour law and development in the long run». Em Shelley Marshall e Colin Fenwick (coordenadores), Labour regulation and development: socio-legal perspectives. Genebra: International Labour Office. 
Gaudêncio, Isabelly Cristinny Gomes e Aldo Cesar Filgueiras Gaudêncio (2016). «Liberdade religiosa e conflitos religiosos no ambiente de trabalho». Revista de Direitos Fundamentais nas Relações do Trabalho, Sociais e Empresariais, 2 (2): 19-34. Disponível em «https://bit.ly/2yax VOo».

Haas, Ingrid Freire (2011). «Globalização e multiculturalismo: impactos da diversidade». Cadernos da Escola de Direito do Centro Universitário Autônomo do Brasil, 1 (14): 1-22. Disponível em «https://bit.ly/2A3moC0».

Jouvenel, Bertrand de (1964). L'art de la conjecture. Mônaco: Rocher.

Kolben, Kevin (2016). «Labour regulation, capabilities, and democracy». Em Shelley Marshall e Colin Fenwick (coordenadores), Labour regulation and development: socio-legal perspectives. Genebra: International Labour Office.

Leite, Fábio Carvalho (2017). «Libertad religiosa y acomodación razonable en Brasil». Revista Latinoamericana de Derecho y Religión, 3 (1): 1-26. Disponível em «https://bit.ly/2OgkSEc».

Lima, Firmino Alves (2010). Contribuições para uma teoria da discriminação nas relações de trabalho. Tese (Doutorado em Direito). Universidade de São Paulo. Disponível em «https://bit.ly/2rPPP5L».

Lima, Luiz Filipe Santos (2015). «Pela isonomia de direitos trabalhistas entre o imigrante estrangeiro e o trabalhador nacional». Revista do Direito do Trabalho e Meio Ambiente do Trabalho, 1 (2): 326-355. Disponível em «https://bit.ly/2ydMwZB».

Makkonen, Timo (2002). Multiple, compound and intersectional discrimination: bringing the experiences of the most marginalized to the fore. Turku: Åbo Akademi University. Disponível em «https://bit.ly/2Lc1vIg».

Martins, Argemiro Cardoso Moreira e Larissa Mituzani (2011). «Direito das minorias interpretado: o compromisso democrático do direito brasileiro». Sequência, 32 (63): 319352. Disponível em «https://bit.ly/2NBpald».

Oliveira, Murilo C. S. (2012). «O resgate do critério da dependência econômica na identificação da relação de emprego na contemporaneidade». Revista da ABET, 11 (1): 114-134. Disponível em «https://bit.ly/2yH5YgP».

Peresie, Jennifer L (2009). «Toward a Coherent Test for Disparate Impact Discrimination». Indiana Law Journal, $87 \quad$ (33): 773-802. $\quad$ Disponível em «https://bit.ly/2IOY0cf».

Ribeiro, Renata Vaz (2014). Abate halal e suas principais características. Monografia (Graduação em Zootecnia). Universidade Estadual de Goiás. Disponível em «https://bit.ly/2LdhANY».

Román Muñoz, Olga Herminda (2017). «Microviolencia en el trabajo, una práctica cotidiana del ejercicio del poder del management en las organizaciones: una reflexión urgente en tiempos de reconciliación». Sociedad y economía, 33: 237-262. Disponível em «https://bit.ly/2rQ7QBaW».

Santin, Valter Foleto (2007). «Migração e discriminação de trabalhador». Revista de Informação Legislativa, 44 (175): 147-153. Disponível em «https://bit.ly/2CDeVvW».

Silva Neto, Manoel Jorge e (2003). «A proteção constitucional à liberdade religiosa». Revista de Informação Legislativa, 40 (160): 111-130. Disponível em «https://bit.ly/2J5Dep6».

Sheppard, Coleen (2011). Multiple discrimination in the world of work. Genebra: International Labour Office. Disponível em «https://bit.ly/2GtlRcu». 
Toledo, Edilene (2017). «Um ano extraordinário: greves, revoltas e circulação de ideias no Brasil em 1917». Estudos Históricos, 30 (61): 497-518. Disponível em «https://bit.ly/2CBw1tY».

Vives, Juan Martin (2017). «La acomodación razonable para la religión en el lugar de trabajo en EE.UU., Canadá y Europa: lecciones de esa experiencia aplicables al ámbito latinoamericano». Revista Latinoamericana de Derecho y Religión, 3 (1): 1-40. Disponível em «https://bit.ly/2A5Kw6U».

Weingartner Neto, Jayme (2007). Liberdade religiosa na Constituição: fundamentalismo, pluralismo, crença, cultos. Livraria do Advogado: Porto Alegre.

\section{Documentos}

Brasil, República Federativa do (2016). Ministério das Mulheres, da Igualdade Racial, da Juventude e dos Direitos Humanos. Relatório sobre intolerância e violência religiosa no Brasil (2011-2015): resultados preliminares. Organização Alexandre Brasil Fonseca e Clara Jane Adad. Brasília: Secretaria Especial de Direitos Humanos. Disponível em «https://bit.ly/2K XdyZ1».

Brasil, República Federativa do. Tribunal Regional Federal da Terceira Região (2018). Apelação Cível $n^{o}$ 0034549-11.2004.4.03.6100/SP. Apelantes: Rádio e Televisão Record S/A e Rede Mulher de Televisão Ltda. Apelados: Ministério Público Federal, Instituto Nacional da Tradição e Cultura Afro-Brasileira e Centro de Estudos das Relações de Trabalho e da Desigualdade. Relatora: Desembargadora Federal Consuelo Yoshida. Órgão julgador: Sexta Turma. São Paulo, 6 de abril de 2018. Disponível em «https://bit.ly/2wGlnjz».

Brasil, República Federativa do. Tribunal Superior do Trabalho (2015). Recurso de Revista 0051400-80.2009.5.21.0017. Recorrente: Companhia Energética do Rio Grande do Norte Cosern. Recorrido: (nome omitido para preservar a intimidade do trabalhador). Relator: Ministro Hugo Carlos Scheuermann. Órgão julgador: Primeira Turma. Brasília, 24 de junho de 2015. Disponível em «https://bit.ly/2yf2Lpg».

Instituto Brasileiro de Geografia e Estatística (sítio). Sistema IBGE de Recuperação Automática - SIDRA. Censo Demográfico 2010: Tabela 137 - População residente, por religião. Disponível em «https://bit.ly/2i94IeF».

Ministério da Indústria, Comércio Exterior e Serviços (sítio). Comex Vis: Principais Produtos Exportados. Disponível em «https://bit.ly/2Lc0xvK». 